\title{
Police Labor Unrest and Lengthy Contract Negotiations: Does Police Misconduct Increase with Time Spent Out of Contract?
}

\author{
Andrea Cann Chandrasekher* \\ UC Davis Law \\ First Version: January 2011 \\ This Version: September 2014
}

\begin{abstract}
Abstract: This paper presents evidence of the effect of labor unrest on labor production in the policing context using data from New York City. When contract negotiations last for an extended period, old contracts can expire before new ones are approved. Working under an expired contract, or being "out of contract," can be costly for police officers both monetarily and psychologically. This paper studies the effect of time spent out of contract on police misconduct using new data and a research design that exploits the fact that different ranks of NYPD officers are out of contract at different points in time and for different lengths of time. I find evidence that incidents of police officer discourtesy and abuse of authority increase with the amount of time spent out of contract; there is no statistically significant relationship between incidents of excessive force and time spent out of contract.
\end{abstract}

${ }^{*}$ I am deeply grateful to Ian Ayres, Sam Buell, John de Figueiredo, Chris Elmendorf, Rachel Harmon, Dan Kessler and Alison Morantz for comments on earlier drafts that improved the paper. David Card, Scott Carrell, Stefano DellaVigna, Barbara Fried, Ann Huff Stevens and participants at the Stanford-Harvard-Yale Junior Faculty Forum, the 2013 NBER Summer Institute and the 5th Annual Southwest Criminal Law Workshop provided invaluable feedback. I am thankful to Marcos Soler and the New York City Civilian Complaint Review Board for providing the misconduct data. I am also thankful to Jean Brewer and the New York City Office of Labor Relations for providing the police and firefighter wage contracts. Any errors are my own. 


\section{Introduction}

What happens when police officers become unhappy and dissatisfied with their contract negotiations? Prior research demonstrates that when police expressions of labor unrest are highly publicized, public safety is rarely jeopardized. Specifically Chandrasekher (2010) shows that ticketwriting slowdowns, a highly publicized labor action where police officers reduce their ticket-writing productivity as a way of exerting financial pressure on city government officials to pass a unionfriendly contract, have no effect on crime rates. The result that highly publicized forms of police labor unrest do not tend to affect public safety is perhaps not surprising; a police union that is attempting to garner public support for its pay raise has every incentive to keep the public happy by maintaining public safety throughout the period of labor unrest.

Not all expressions of labor frustration ${ }^{1}$, however, may be well-publicized. This paper seeks to determine whether other, more subtle manifestations of labor unrest may be at work during police labor negotiations that may negatively impact public safety. In particular, this paper investigates the general relationship between police misconduct levels and the amount of time spent working under an expired contract, even in the absence of any publicized expressions of labor unrest. As is dictated by labor law in some states, when a police union's contract expires before it is able to successfully negotiate a new contract with the city, the officers typically continue to work and collect wages according to the old contract's pay rate. When a new contract is ultimately negotiated, the police officers are retroactively paid the difference between the new and old wage rates for the time spent "out of contract," or working under an expired contract. The amount paid, however, does not include interest. Therefore, being out of contract can be costly to a police officer, especially when the labor negotiations last for multiple years. This financial loss, combined with the antagonistic labor negotiations and the uncertainty of the outcome have the potential to increase the overall level of labor unrest, even in the absence of an official public demonstration of the unrest such as a ticket-writing slowdown. Using data from New York City, I quantitatively estimate the impact of being out of contract on the level of police misconduct. My results show that working under an expired contract, in and of itself, is positively related to police misconduct. Specifically, as

\footnotetext{
${ }^{1}$ In what follows, I will use the terms labor frustration, labor unrest, and labor strife interchangeably.
} 
the proportion of the last 24 months spent out of contract increases by 0.10 , the substantiated or verified misconduct rate increases by $9 \%$. The types of substantiated misconduct complaints that are most affected are abuses of authority and discourteous behavior; there is no statistically significant effect on excessive force complaints.

\section{Literature Review}

This paper contributes to the economics literature on the effect of labor frustration on labor production. This literature seeks to understand how the quantity and quality of goods produced may or may not be affected when workers become dissatisfied and unhappy because of a disappointing labor climate, typically concerning worker compensation. This literature is broad in that it covers both private sector and public sector workers. Mas (2006) studies final-offer arbitration outcomes for New Jersey police officers involved in salary contract disputes with the city. During final-offer arbitration, both sides give the arbitrator their proposed salary bids and the arbitrator must choose between them. The arbitrator's choice is binding on both parties. Mas shows that police officer productivity decreases (in terms of lower arrest rates and higher crime rates) in the months following an arbitration loss relative to the months following an arbitration win. Furthermore, Mas demonstrates that these losses are larger when the ultimate arbitration award is farther from the officers' desired award. Mas' analysis provides convincing evidence that police officer productivity is affected by labor unrest. One difficulty that Mas faces in his study is that he does not have access to data on police misconduct for New Jersey police officers. As a result, he is not able to investigate the effect of disappointing contract outcomes on police misconduct-which he acknowledges would be the ideal measure of productivity in the public safety context. ${ }^{2}$

In another paper, "Strikes, Scabs, and Tread Separations: Labor Strife and the Production of Defective Bridgestone/Firestone Times", Mas and Krueger confirm the relationship between labor frustration and product quality in the private sector. The authors find strong evidence linking the Firestone defective-tire recall of 2000 to an earlier period of labor strife in the Firestone factories when workers were on strike.

\footnotetext{
${ }^{2} \operatorname{Mas}(2006)$, pg. 788.
} 
While Mas (2006) and Mas and Krueger (2004) present strong evidence of a relationship between labor frustration and product quantity/quality, two other papers in the literature do not. In a study of strikes by Pennsylvania teachers from 1997-2006, Turner (2008) finds that labor strikes had no effect on the education production process, as measured by student test scores. Similarly, Chandrasekher (2010) finds that a major labor action by New York City Police officers in 1997, a ticket writing slowdown, had no effect on crime rates. Thus, one deficiency in the labor frustrationproductivity literature is that it currently offers no explanation for why some instances of labor frustration negatively impact the quality and quantity of production and others don't. In this paper, I offer up one possible theory: that, at least as it concerns public sector employees, the way in which labor frustration is expressed matters. Specifically, highly publicized forms of labor frustration, such as formal labor strikes (Turner 2008) and slowdowns (Chandrasekher 2010), are less likely to impact labor production because public sector employees know that during these highly publicized labor actions, their work products (public education and public safety, respectively) are highly scrutinized and any perceived reductions in productivity would hurt the public's support for their cause. Other more subtle expressions of labor frustration, such as those that manifest after the announcement of a disappointing arbitration outcome (Mas 2006) or those that manifest after the expiration of a contract (current paper), may be more likely to negatively impact labor production because they are less scrutinized. For private sector employees, on the other hand, the public's support for their cause should matter less since their contract negotiations are with private business owners, rather than the city. This perhaps explains why the Firestone labor strike, a highly publicized expression of labor frustration, nonetheless led to a reduction in the quality of the production of Firestone tires.

The current paper, then, seeks to extend and contribute to this literature on the production consequences of labor unrest in three ways: first, by offering up a unifying theory that explains why the literature has failed to find a relationship between labor frustration and labor production in certain contexts; second, by looking at the effect of labor frustration on police misconduct (a productivity outcome variable that was unavailable in the Mas 2006 analysis due to data limitations); and third, by examining the effect on labor productivity of working under an expired contract-a 
different type of labor unrest that has not yet been studied in this literature but that has practical importance for certain classes of workers like police officers who often work under expired contracts. (See Section 3 for more details on police contract negotiations).

\section{Background on the NYPD Contracting Process}

As with other public unions, the police contract negotiation process is often lengthy and adversarial. If the negotiation process goes on too long, police contracts can expire before new ones are approved by the union. When this happens, the police departments are "out of contract" or working under an expired contract. New York law dictates that when a contract expires before a new one is ratified, the officers can continue to work and be paid under the terms of the expired contract until the new contract is ratified. Once the new contract is ratified, the police are awarded back pay which is equivalent to the difference between the new (and presumably higher) pay rate and the old pay rate multiplied by the number of months worked while out of contract.

Since police officers do continue to get paid when they are out of contract and lost wages are ultimately awarded through "back pay", it might seem that being out of contract is not a bad outcome for police. There are, however, several disadvantages that police officers may face as a result of being out of contract. First and most obvious, pay raises are delayed. As Mas' research indicates, to the extent that officers expect timely pay raises, any delays in this regard could be psychologically disappointing which may have an effect on police productivity in terms of arrest or crime rates. Secondly, when back pay is ultimately awarded, officers are not paid any interest on the delayed wages. Thus, the longer that a police officer spends out of contract, the more money she stands to lose. Third, the NYPD contract negotiating process can be extremely antagonistic and the outcomes can be difficult to predict. As a result, officers might become more frustrated the longer they spend out of contract.

Another dimension of the NYPD contracting process (one that I ultimately exploit in my research design) is that the different ranks of officers have different unions that negotiate indepen- 
dently with the city for their contract. There are five basic ranks in the NYPD and they each have their own union. Specifically, the rank and file police officers' union is called the Patrolmen's Benevolent Association, the detectives' union is called the Detectives' Endowment Association, the sergeants' union is called the Sergeants' Benevolent Association, the lieutenants' union is called the Lieutenants' Benevolent Association, and finally the captains' union is called the Captains' Endowment Association. I drop captains from my analysis because their misconduct rate is nearly always zero over the sample period. My sample thus includes four ranks of officers: rank and file police officers, detectives, sergeants, and lieutenants. (In what follows, I will use the term "patrolmen" to refer to the rank and file police officers and the term "police officers" to generally refer to members of the police force, regardless of rank.) As a result of the independent negotiating and contracting processes, each of the ranks was out of contract at different points in time and for different lengths of time during my sample period. Appendix Table A gives the dates of the out of contract periods for each of the ranks.

\section{Data}

\subsection{NYPD Misconduct Data}

I obtained misconduct data from the New York City Civilian Complaint Review Board (CCRB) via a Freedom of Information Law request. My data contain all complaints lodged against New York City police officers for allegations of misconduct occurring between January 1, 1996 and August 31, 2007. The data include various details about the complaint including date of incident, date of report, type of misconduct alleged (excessive force, abuse of authority, discourtesy, or offensive language) ${ }^{3}$, and whether or not the allegation was ultimately substantiated (meaning independently verified) by the CCRB. The data also include the rank of the officer.

\footnotetext{
${ }^{3}$ Recall that even though our literature review focused on police brutality, in our analysis we will study police misconduct generally (i.e.--all four categories).
} 


\subsubsection{Construction of the Misconduct Rate}

When a citizen reports police misconduct to the CCRB, a new case file or complaint is opened. All allegations of misconduct arising out of that incident are categorized under a single complaint number. However, that single complaint may cover multiple victims and multiple allegations of misconduct against multiple officers. ${ }^{4}$ For example, if a man were to allege that three police officers each assaulted him and then threatened to arrest him, he would file one complaint with six allegations: for each officer there would be an allegation of excessive force and an allegation of abuse of authority.

To construct the rank-specific, monthly misconduct rate, I divide the total number of officerincidents per rank per month by the total number of police officers of that rank employed by the police department in that year. ${ }^{5}$ The number of officer-incidents is the total number of separate incidents each officer is accused of in a particular month. For example, if a single officer were to engage in three different acts of misconduct in a particular month, each of those three acts would be included in the numerator of the misconduct rate. An alternative metric for the misconduct rate would be the total number of officers accused of misconduct per month divided by the rank size. Since I am chiefly interested in detecting changes in the level of misconduct experienced by the NYC population, I prefer the first metric since repeat officer-offenders are counted multiple times in the numerator. Functionally, however, the two metrics (the officer-incident-based misconduct rate and the officer-based misconduct rate) are very similar because officers typically are not accused of more than one separate incident of misconduct per month. Furthermore, for completeness, all analyses in the paper were computed with both the officer-incident-based misconduct rate and the officer-based misconduct rate and none of the results were substantively different.

\footnotetext{
${ }^{4}$ CCRB Status Report Jan-Dec 2001. Available from http://www.nyc.gov/html/ccrb/html/reports.html.

${ }^{5}$ Note that the substantiated misconduct rate is computed in exactly the same way, using substantiated misconduct officer-incidents rather than all misconduct officer-incidents. The substantiated misconduct rate is the primary outcome variable of interest in my analysis.
} 


\subsubsection{Data Limitations}

There are three limitations of the data. First, the data only represent misconduct claims filed with the CCRB. In general, complaints of misconduct against the police can be filed with the CCRB, with the NYPD Internal Affairs Bureau, or with the NYPD themselves at a particular precinct. Unfortunately, misconduct data from the NYPD were not available to me. Therefore, my results can only speak to the effect of labor unrest on misconduct claims where (1) the alleged victim decided file a complaint and (2) they filed that complaint with the CCRB.

Secondly, my data only includes misconduct complaints in which at least one of the accused officers was ultimately identified during the course of the investigation. This could be a potential source of bias if the identification rate changed over time in a way that was correlated with the labor unrest. If, for example, the total number of misconduct claims stayed the same or declined during the out of contract periods but the identification rate increased because CCRB personnel had more time to investigate each case, then the number of identified complaints could be spuriously biased upwards. I was able to obtain monthly data on the total number of complaints (both identified and unidentified) from the CCRB in order to explore this question. The results showed that the identification rate remained roughly stable between 60 and 70 percent throughout my entire sample period. $^{6}$

The third limitation of the data concerns the substantiated misconduct rate. The substantiated misconduct rate is the verified misconduct rate-to be distinguished from the "regular" or total misconduct rate which includes both substantiated and unsubstantiated misconduct officer-incidents. When the CCRB receives a complaint, they investigate it to see if it has merit. The investigation will often involve a detailed interview with the complaining party as well as with the accused officer. After a thorough investigation has been made, the CCRB review board hears all the evidence and makes a determination as to whether the accusation is substantiated or not. Thus, the substantiated misconduct rate is, in a sense, the "true" misconduct rate-i.e. the misconduct rate that has been purged of all unfounded allegations. As such, the substantiated misconduct rate is the primary outcome variable of interest in my analysis.

\footnotetext{
${ }^{6}$ Tables are available from the author upon request.
} 
The one limitation of the substantiated misconduct rate is that the substantiation review process requires a lengthy investigation that can often exceed a year. As a result, my sample of substantiated misconduct complaints is smaller than my sample of misconduct complaints. In particular, while both samples begin in January 1996, the substantiated sample stops in October 2006 because claims made in November 2006 and after were still in the substantiation review process at the time the data were made available to me. The full misconduct sample extends until August 2007.

\subsection{Contract Data}

Details on the dates that the four police unions were in and out contract come from the NYC Office of Labor Relations. The New York City Office of Labor Relations provided all of the labor contracts that were negotiated and signed from 1996 to 2007. During this period, the Patrolmen's Benevolent Association negotiated five contracts and the Sergeants' Endowment Association, the Detectives' Endowment Association, and the Lieutenants' Benevolent Association each negotiated four contracts. I used these contracts to identify the official dates of the contract agreements. The time out of contract was defined as the period from the ending date of the previous contract to the date that the next contract was signed by the NYC Labor Relations Commissioner. ${ }^{7}$ The signature date is the date when the contract and all wage increase details become finalized. As such, it is a proxy for the end of the officers' labor unrest.

Appendix Table A lists the contract dates as well as the periods that each union spent out of contract and in contract. As an example of how the out of contract and in contract periods were defined, take the case of the PBA's 1995-2000 contract (first row). The 1995-2000 PBA contract was due to start on 8/1/1995. However, as of that date, the PBA and the mayor's office had still not agreed to the contract's terms. Negotiations continued for two years until, on 12/12/1997, the Labor Relations Commissioner signed the contract. Accordingly, the period 8/1/1995-12/11/1997 is defined as the out of contract period and $12 / 12 / 1997$ to $7 / 31 / 2000$ is defined as the in contract period.

\footnotetext{
${ }^{7}$ Of course, the labor union must also agree to the terms of the contract. The Labor Relations Commissioner signs the contract after the union membership has voted to ratify its terms. Conversation with Jean Brewer 2/19/2013.
} 


\section{Analysis}

\subsection{Descriptive Statistics}

My sample covers 99,444 misconduct allegations, lodged against officers from January 1996 to August 2007, and 6,533 substantiated misconduct allegations, lodged against officers from January 1996 and October 2006. Though my main analysis will focus on the number of officer-incidents rather than on the number of allegations, I start my analysis with a detailed explanation of these underlying allegations. To begin, most of the 99,444 allegations lodged against the police during my sample period were deemed meritless by the CCRB. As shown in Table 2, $58.7 \%$ of the allegations were judged to be unsubstantiated or unfounded. Another $18.4 \%$ of allegations were administratively closed because either the complainant or victim was unavailable or uncooperative, and $4.1 \%$ of allegations were resolved via mediation or conciliation. Only 6,533 or $6.6 \%$ of allegations were substantiated by the CCRB-meaning that they were verified through an independent investigation.

Because I am primarily concerned with substantiated misconduct allegations, Table 3 breaks down the 6,533 substantiated misconduct allegations by type: excessive force, abuse of authority, discourtesy, and offensive language. Abuse of authority allegations are by far the most numerous, comprising $60 \%$ of all allegations; excessive force, discourtesy, and offensive language allegations account for $21 \%, 17 \%$ and $3 \%$ of all allegations, respectively. An investigation of the subcategories within the four main categories of allegations is also interesting. Most of the excessive force allegations (67.23\%) are for physical force which includes any type of pushing, shoving, or hitting. The act of improperly pointing a gun is the second most common type of excessive force alleged (6.01\%). Within the category of abuse of authority, the most common types of substantiated misconduct alleged are improper frisk and/or search and (14.80\%) and improper question and/or stop $(13.03 \%)$. This is not surprising given the rapid growth in the NYPD's stop and frisk program over the 2000s. ${ }^{8}$ By far the most common type of discourtesy alleged is discourteous words (86.65\%). Within the offensive language category, racial hate speech is the predominant type of substantiated

\footnotetext{
${ }^{8}$ Reference
} 
misconduct alleged (57.99\%).

I now turn to analyzing trends in the number of officer-incidents of both substantiated and total misconduct, with the ultimate goal of determining whether there is a relationship between the number of officer-incidents and police labor unrest. As mentioned above, there were 6,533 substantiated allegations of police misconduct. These 6,533 substantiated allegations involved 3,654 officer-incidents. (See Table 1.) This means that there were 3,654 different instances in which an officer was accused of being involved in a substantiated misconduct incident. For each of these 3,654 officer-incidents, I determined the exact year and month that the incident occurred as well as the rank of the officer accused. I then counted the number of substantiated officer-incidents per rank, in each year and month, from January 1996 to October 2006 (130 months in total). Ultimately, my substantiated misconduct sample includes 520 observations - 130 observations for each of the four ranks. The exact same sample construction process was followed for the 99,444 total misconduct allegations that involved 51,632 officer accusations. Thus, I also have a total misconduct sample that covers the period from January 1996 to August 2007 and includes 560 observations - 140 observations for each of the four ranks.

A preliminary analysis of my substantiated and total misconduct samples shows that both types of misconduct are rare. As is shown in Table 4, on average, there are only 7 substantiated officerincidents alleged per rank-month and 92 total officer-incidents alleged per rank-month. Given the average rank size of 9,093 , this translates to an average substantiated misconduct rate of $0.07 \%$ and an average misconduct rate of $0.85 \%$ for all ranks combined.

When the substantiated misconduct rate is analyzed for each rank separately, some predictable patterns emerge. Specifically, officers at the patrolmen and sergeant rank have the highest substantiated misconduct rates $(0.076 \%$ and $0.082 \%$ respectively) followed by detectives $(0.069 \%)$ and lieutenants $(0.058 \%)$. Patrolmen and sergeants also have higher total misconduct rates than the other ranks. The higher misconduct rates (both substantiated and total) for patrolmen and sergeants accord with my expectations given that these two groups have a higher level of interaction with the public than lieutenants and detectives. ${ }^{9}$

\footnotetext{
${ }^{9}$ http://en.wikipedia.org/wiki/New_York_City_Police_Department\#Ranks_of_the_NYPD
} 
Figures 1 and 2 graph the substantiated misconduct rate and the total misconduct rate, respectively, for each rank over the entire sample period. One thing that is immediately noticeable from the total misconduct graph is that there is a strong dip in the total misconduct rates of all ranks during the $9 / 11$ period, which is indicated in the graph with a vertical red line. This dip is likely due to a variety of factors including: a lower level of policing during that time as officers of all ranks were heavily involved in the activities surrounding the events of $9 / 11$, a lower level of actual police misconduct given the sense of national camaraderie at the time, and a lower likelihood of citizens filing accusations against police officers during this time out of reverence to fallen officers.

Does the misconduct rate vary by contract status? To give a graphical sense of the relationship between police misconduct and time spent working under an expired contract, as well as a sense of the differing periods of labor strife for the each of the ranks, Figures 3A through 3D graph the substantiated misconduct rate and the "time spent working out of contract" variable for each rank separately. As will be explained in greater detail in the panel data analysis section (Section 5.2.1), the "time spent working out of contract" variable is a variable which gives the proportion of the last 24 months that a particular rank's union spent working under an expired contract. The positive relationship between the substantiated misconduct rate and the time spent out of contract variable, especially for patrolmen, sergeants and lieutenants, is striking. For example, Figure 3A, the patrolmen figure, shows a very strong downward trend for the substantiated misconduct rate during the 1997-2000 in contract period and a very strong upward trend for the post-2000 out of contract period. The relationship between the substantiated misconduct rate and time spent out of contract is also visually perceptible for sergeants (Figure 3B) and lieutenants (Figure 3C). For detectives (Figure 3D), a graphical correspondence between substantiated misconduct and the time spent out of contract is less evident. When one looks at the relationship between the total misconduct rate and time spent working out of contract by rank (Figures 4A through 4D), it is clear that a correspondence between the total misconduct rate and labor unrest exists as well, though the relationship is weaker than with the substantiated misconduct rate.

While this graphical evidence is supportive of a positive relationship between police misconduct and labor strife, it is possible that other non-contract factors are responsible for the patterns 
present in the data. For example, one concern is that most ranks exhibit a gradual increase in their respective misconduct rates from about 2000 onwards. If these increases are instead attributable to citywide secular factors, such as gradual changes in the demographic profile of the New York City population or increases in the overall activity level of the police department, then simple correlations between the misconduct rate and time spent out of contract will be biased. To account for this, I now turn to my regression analysis, which allows me to very explicitly control for some of the secular factors that could be affecting officer misconduct.

\subsection{Poisson Regression Analysis}

I use Poisson regression to model substantiated and total misconduct officer-incidents because both variables are non-negative and integer-valued. The Poisson regression model is especially well suited for the substantiated misconduct officer-incidents because it often takes on the value zero ( $10 \%$ of the sample). In a general Poisson regression model, $y_{i t}$ conditional on $\mathbf{x}_{i t}$ follows a Poisson distribution. The density function is:

$$
f\left(y_{i t} \mid \mathbf{x}_{i t}\right)=\frac{e^{\lambda_{i t}} \lambda_{i t}^{y_{i t}}}{y_{i t} !} \text { for } y_{i t}=0,1,2 \ldots
$$

In addition, the conditional mean parameter, $\lambda_{i t}$, is strictly greater than zero since

$$
E\left(y_{i t} \mid \mathbf{x}_{i t}\right)=\lambda_{i t}=\exp \left(\mathbf{x}_{i t}^{\prime} \beta\right)
$$

In this case, $y_{i t}$ is $y_{i j m}$, the number of times that a substantiated misconduct incident is lodged against an officer of rank $i$ in year $j$ and month $m$. In alternative specifications, the dependent variable is the number of times any misconduct incident (substantiated or not) is lodged against an officer of rank $i$ in year $j$ and month $m$. Likewise, $\mathbf{x}_{i t}$ is $\mathbf{x}_{i j m}$, a vector of variables that are correlated with $y_{i j m}$. Before moving on to a description of the panel data research design and estimation, a couple of things are worth pointing out as a preliminary matter. The first issue concerns overdispersion in the dependent variable. Both the substantiated misconduct incident data and the total misconduct incident data exhibit signs of overdispersion in the raw samples. 
(As shown in Table 4, there are an average of 6.85 substantiated misconduct officer-incidents per month $(\mathrm{SD}=7.83)$ and 92.2 misconduct officer-incidents per month $(\mathrm{SD}=107.37)$. When data are overdispersed, MLE Poisson regression standard errors are inconsistent, and as a practical matter, often too small. There are two possible ways of dealing with the problem of overdispersion in Poisson models. One method is to estimate a negative binomial model which specifies that the variance is a multiple of the mean. Another method is to calculate Poisson robust standard errors. The advantage of this method is that it does not put any constraints on the functional form of the overdispersion. Both methods provide consistent standard error estimates if the conditional mean assumption $\left(E\left(y_{i t} \mid \mathbf{x}_{i t}\right)=\lambda_{i t}=\exp \left(\mathbf{x}_{i t}^{\prime} \beta\right)\right)$ holds. ${ }^{10}$ For the analyses in this paper, the choice between the negative binomial model and the Poisson model with robust standard errors made very little difference in the results. Both methods yielded the same qualitative results in terms of the size and statistical significance of the parameter estimates. In what follows, I present the Poisson results with the robust standard errors. ${ }^{11}$

The second general matter is the use of an exposure variable. When the dependent variable in a Poisson regression has a natural interpretation as a rate, it is common to include the denominator variable of the rate (called the exposure variable) on the right-hand side in its natural logarithm form and with its coefficient constrained to be one. ${ }^{12}$ Here, because I want to control for differences in the level of rank-specific misconduct that are due to differences in rank size, I use rank size as an exposure variable in all Poisson regressions throughout this paper. Specifically, this means that $\ln$ (rank size) enters as a control variable in the Poisson regressions and its coefficient is constrained to be one. The use of rank size as an exposure variable makes the Poisson model into a model that explains misconduct rates instead of a model that explains misconduct counts. ${ }^{13}$

\footnotetext{
${ }^{10}$ See Cameron and Trivedi (1998) and Krueger and Mas and (2004) for a discussion of Poisson regression models and strategies for dealing with overdispersion.

${ }^{11}$ Results from the negative binomial regressions are available from the author upon request.

${ }^{12}$ The classical examples of exposure variables discussed in Cameron and Trivedi (1998) are the number of miles driven when the count data are number of accidents or population size when the count data are disease incidence. (p81).

${ }^{13}$ See Osgood (2000) for a discussion of the use of exposure variables in Poisson regression models.
} 


\subsubsection{Panel Data Analysis}

In this section, I analyze the relationship between time spent out of contract and officer misconduct using a monthly panel dataset. As mentioned in Section 5.1, for each rank, I have 130 monthly substantiated misconduct observations and 140 monthly total misconduct observations. My research design exploits the fact that different ranks were out of contract for different lengths of time and at different points of time to identify the effect of interest. This allows me to use each rank's in contract spell as a control for what would have happened to an out of contract rank if they had been in contract.

More formally, $y_{i j m}$ is either the number of substantiated or total misconduct incidents lodged against officers of rank $i$, in year $j$ and month $m$. I hypothesize that $y_{i j m}$, conditional on $\mathbf{x}_{i j m}$, follows a Poisson distribution with conditional mean parameter equal to $\exp \left(\mathbf{x}_{i j m}^{\prime} \beta\right)$. The primary covariate of interest in $\mathbf{x}_{i j m}$ is a variable that measures the proportion of the last 24 months that officers of rank $i$ have been working under an expired contract. If police labor unrest affects police misconduct in the hypothesized way, then the coefficient on this variable will be positive, implying that as the proportion of time spent working under an expired contract increases, police misconduct increases. In addition to the labor unrest variable, $\mathbf{x}_{i j m}$ includes two variables that control for the overall level of police activity (the number of felony arrests made per month across all ranks and the number of parking tickets issued per month across all ranks), an indicator for September 2001, and seasonal dummies. I also include a series of fixed effects in the Poisson regressions. Specifically, I include rank fixed effects to control for differences between ranks in terms of their average misconduct levels, year fixed effects to control for citywide trends (like the poverty rate, unemployment rate, etc.) that could affect misconduct rates for all the ranks, and rank-by-year fixed effects to control for any rank-specific factors that vary over time and are correlated with officer misconduct. These rank-by-year fixed effects are crucial to the analysis because rankspecific time-variant controls were not available from any data provider for my analysis. Finally, the size of each rank is the exposure variable and so I include its natural logarithm in all of the Poisson regressions with its coefficient constrained to be 1. 
Main Results Labor unrest has a large and statistically significant effect on substantiated misconduct. Specifically, the coefficient of 0.9254 implies that as the proportion of the last 24 months spent working under an expired contract increases by 0.10 , the substantiated misconduct rate increases by $9 \% \cdot{ }^{14},{ }^{15}$ Substantiated misconduct is also affected by felony arrests; one thousand additional felony arrests are associated with a $17 \%$ increase in the substantiated misconduct rate. And, as we saw in the descriptive analysis, sergeants, detectives and lieutenants all have significantly lower rates of substantiated misconduct than patrolmen.

The link between labor unrest and total reported misconduct (i.e.--verified and unverified misconduct combined) is less strong. A 0.10 increase in the proportion of the last two years spent working under an expired contract leads to only a $3.5 \%$ increase in the total misconduct rate. There is also a weaker link between the total reported misconduct rate and felony arrests $(9 \%$ here vs $17 \%$ for substantiated misconduct). Interestingly, the number of parking tickets issued is statistically correlated with total reported misconduct but not with substantiated misconduct. This perhaps indicates a tendency amongst New Yorkers to lodge frivolous, retaliatory complaints against police officers in response to receiving parking tickets. Similarly, the total reported misconduct rate, but not the substantiated misconduct rate, was affected by the September 11th terrorist attacks. The total reported misconduct rate was down by $20 \%$ during the month of the terrorist attacks. As with substantiated misconduct, sergeants, lieutenants, and detectives all have lower total misconduct rates than patrolmen, even after controlling for ranks size.

I also investigate the relationship between labor unrest and different types of substantiated misconduct. For this analysis, I categorize each of the 3,564 substantiated misconduct officerincidents by its most serious allegation. As before, I then construct a panel data set that has the number of excessive force, abuse of authority, discourtesy, and offensive language officer-incidents per rank, year and month. Using the same Poisson regression specification as before, I find that working under an expired contract has an effect on the substantiated abuse of authority and discourtesy misconduct rates; a 0.10 increase in the proportion of the last 24 months spent working

\footnotetext{
14 This result is robust to various out of contract time periods.

${ }^{15}$ The exact percentage change in the mean response is given by the forumula $(\exp (\beta)-1) * 100$. For simplicity, here I approximate the percentage change in $E(y \mid x)$ for a one-unit change in $x$ using the usual $\beta^{*} 100$ semi-elasticity formula. Such approximations are valid since the $\beta^{\prime} s$ of interest are small (typically less than 1).
} 
under an expired contract increases the substantiated abuse of authority misconduct rate by $10 \%$ and the substantiated discourtesy misconduct rate by $16 \%$. See Table 7. A statistically significant effect on the substantiated excessive force misconduct rate is not detected in the data. ${ }^{16}$

Exogeneity In theory, police contract status (i.e.--whether or not a particular union is working under an expired contract in a given month) may itself be affected by the underlying police misconduct rate. The level of police misconduct is an observable measure of police productivity. As such, high rates of police misconduct might be a point of contention in contract negotiations, perhaps leading to a delay in the process. If police contract status is indeed affected by police misconduct, estimates of the effect of contract status on police misconduct will be subject to simultaneity bias.

Fortunately, as a result of two specific institutional details, it is unlikely that police contract status will be influenced by police misconduct. First, and most importantly, police productivity standards (for misconduct, clearance rates, arrest rates, etc.) have historically never been a part of the written contracts between the police unions and the city. ${ }^{17}$ Generally, NYPD contracts cover the basic topics (such as salary, benefits, hours, overtime, and union recognition), without any mention of police performance. In fact, in the 17 contracts reviewed for this study, (5 for the PBA, 4 for the SBA, 4 for the LBA, and 4 for the DEA), none mentioned any type of police productivity standard.

Second, the city agency that is responsible for collecting and verifying reports of police misconduct, the CCRB, is wholly separate from the city agency that is responsible for negotiating wage contracts with the various police unions, the Office of Collective Bargaining. The two agencies operate completely independently and do not coordinate their efforts.

\subsection{Robustness Checks}

\footnotetext{
${ }^{16}$ There is not enough data to reliably estimate the effect of labor unrest on offensive language incidents. More specifically, in order to carry out this misconduct-type analysis, I categorize all incidents by their most serious allegation-where excessive force is the most serious allegation, followed by abuse of authority and discourtesy; offensive language is the least serious allegation type. This recategorization results in an insufficient number of offensive language incidents (only 5 in the entire data set) to conduct a reliable analysis.

${ }^{17}$ Conversation with Jean Brewer.
} 
I run two robustness checks to test the validity of the results. First, I rerun the analysis using a log-linear regression model instead of a Poisson regression model in order to verify that my results are not being driven by the assumption of a Poisson error structure. Second, I investigate how my results vary with changes in the length out of contract time window.

\subsubsection{Log-Linear Functional Form}

The Poisson regression model used in Section 5.2 makes two assumptions. The first assumption is that the conditional mean of $y$ is a $\log$-linear function of $\mathbf{x}^{\prime} \beta$. The second assumption is that $y$ and $\varepsilon$ follow a Poisson distribution. An alternative specification is the log-linear model which retains the first assumption but replaces the second assumption with one of normality. Specifically, the log-linear model assumes that:

$$
\begin{aligned}
& E(y \mid \mathbf{x})=\exp \left(\mathbf{x}^{\prime} \beta\right) \\
& \ln (y \mid \mathbf{x}) \sim N\left(\mu, \sigma^{2}\right)
\end{aligned}
$$

In order to assure that the results are not dependent on the assumption of $y$ and $\varepsilon$ following a Poisson distribution, an analysis is run using a log-linear functional form where the natural logarithm of the substantiated misconduct rate and the natural logarithm of the total misconduct rate are used as the dependent variables. The disadvantage of this approach, of course, is that zero outcomes can no longer be included in the model. As a result, the substantiated misconduct sample drops from 520 observations to 451 observations, a reduction of 13\%; the total misconduct rate sample is unaffected. For completeness, the simple linear model with the dependent variables not logged is also run in order to assure that the exclusion of the zero outcome observations is also not affecting the results. ${ }^{18}$

The results from the log-linear model are qualitatively very similar to the results from the

\footnotetext{
${ }^{18}$ I also run the log-linear model with $\ln ($ Substantiated Misconduct Rate +0.1$)$ and $\ln ($ Substantiated Misconduct Rate +0.01$)$ as the dependent vaiables. The results from these additional log-linear specifications and from the simple linear model all yielded qualitatively similar results. Tables are available from the author upon request.
} 
Poisson model. See Table 9 for the log-linear results. Contract status, or the proportion of the last 24 months spent working under an expired contract, affects both substantiated misconduct and total misconduct. The coefficients on the control covariates all have the same sign across the log-linear model and the Poisson model.

\subsubsection{Length of Time Out of Contract}

In all specifications throughout the paper, I have used "proportion of the last 24 months spent out of contract" as the contract status variable. In this section, I investigate whether the effect varies according to how long the time horizon window is. Specifically, I experiment with six additional treatment variables: the proportion of the last $6,12,18,24,36$ and 48 months spent working under an expired contract. Table 10 has the results. For substantiated misconduct (first column), we see that there is an increase in the effect size from 6 to 12 to 18 to 24 to 36 months. In fact, the effect size increases monotonically from $1.3 \%$ for the 6 month time window to $12 \%$ for the 36

month time window. The effect size then drops off for the 48 month time window to $1 \%$. The same pattern can be seen for total misconduct (second column). Again, the effect size increases monotonically from the 6 month time window to the 36 month time window, then decreases for the 48 month time window.

Why do the 24 and 36 month time windows fit the data best, with a decrease in the correlation at the 48 month time window? A likely explanation for this is that police officers take a long view in considering how to respond to their contract status. Since New York police officers are typically out of contract for several years at a time, it is likely that they base their current misconduct behavior on their contract status over the last several years rather than their contract status over the more recent past. Koszegi and Rabin's 2006 paper on reference dependence and rational expectations provides some insight here. In that paper, Koszegi and Rabin posit that an agent's rational expectation is the best candidate for her reference point. Applying that reasoning to the current context, if police officers rationally expect to be out of contract for, say, two years at a time, then it would make sense that two years would be their reference point; it follows, then, that their behavior today would be most strongly affected by the proportion of the last two years that 
they had spent out of contract.

What remains, then, is to determine the police officers' rational expectation with respect to contract status. To get an idea of how long each rank was typically out of contract and thus could rationally expect to be out of contract, I calculated the median duration of the out of contract spells for each rank from 1980 to 2008 . Table 11 has these median duration times as well as the total number of out of contract spells, listed by rank. The median duration of the out of contract spells ranged from 25 months to 36.5 months-exactly the length of the time windows that were most highly correlated with police misconduct. Thus, the fact that police officers' misconduct is most highly correlated with their 24 and 36 month contract status is consistent with that time frame being their rational expectation and reference point.

\section{Conclusion}

This paper provides evidence that subtle, non-publicized forms of labor frustration are related to labor production. In particular, in New York City, when NYPD officers are forced to work under an expired contract, levels of misconduct increase with the amount of time officers spend out of contract. The effect exists even in the absence of a more formal type of publicized police labor action such as a ticket-writing slowdown. These results have implications for the economics literature on the general effect of labor frustration on labor production. Specifically, the results imply that the way in which public sector workers express their labor frustrations may impact the degree to which labor production is negatively affected, with highly publicized expressions of labor frustration being less likely to have a negative effect.

\section{Works Cited}

- Cameron, A.C., \& Trivedi, P. (1998). Regression Analysis of Count Data. West Nyack, NY: Cambridge University Press.

- Champion, D. (2001). Police Misconduct in America. Santa Barbara, CA: ABC-CLIO,Inc. 
- Chandrasekher, A. (2010). "The Effect of Order-Maintenance Policing on Serious and NonSerious Crime: Evidence from a Quasi-Experiment". Working Paper.

- Koszegi, B. \& Rabin, M. (2006). "A Model of Reference-Dependent Preference." Quarterly Journal of Economics, 121(4), 1133-1166.

- Lersch, K., \& Mieczkowski, T. (2005). "Violent Police Behavior: Past, Present, and Future Research Directions." Aggression and Violent Behavior, 10, 552-568.

- Mas, A. (2006). "Pay, Reference Points, and Police Performance." Quarterly Journal of Economics, 121(3), 783-821.

- Mas, A. and Krueger, A. (2004). "Strikes, Scabs, and Tread Separations: Labor Strife and the Production of Defective Bridgestone/Firestone Tires." Journal of Political Economy, 112, 253-289.

- Osgood, D. W. (2000). "Poisson-Based Regression Analysis of Aggregate Crime Rates." Journal of Quantitative Criminology, 16(1),21-43.

- Turner, A.(2008). "Labor Strife in Public Schools: Does it Affect Education Production?". Working Paper. 


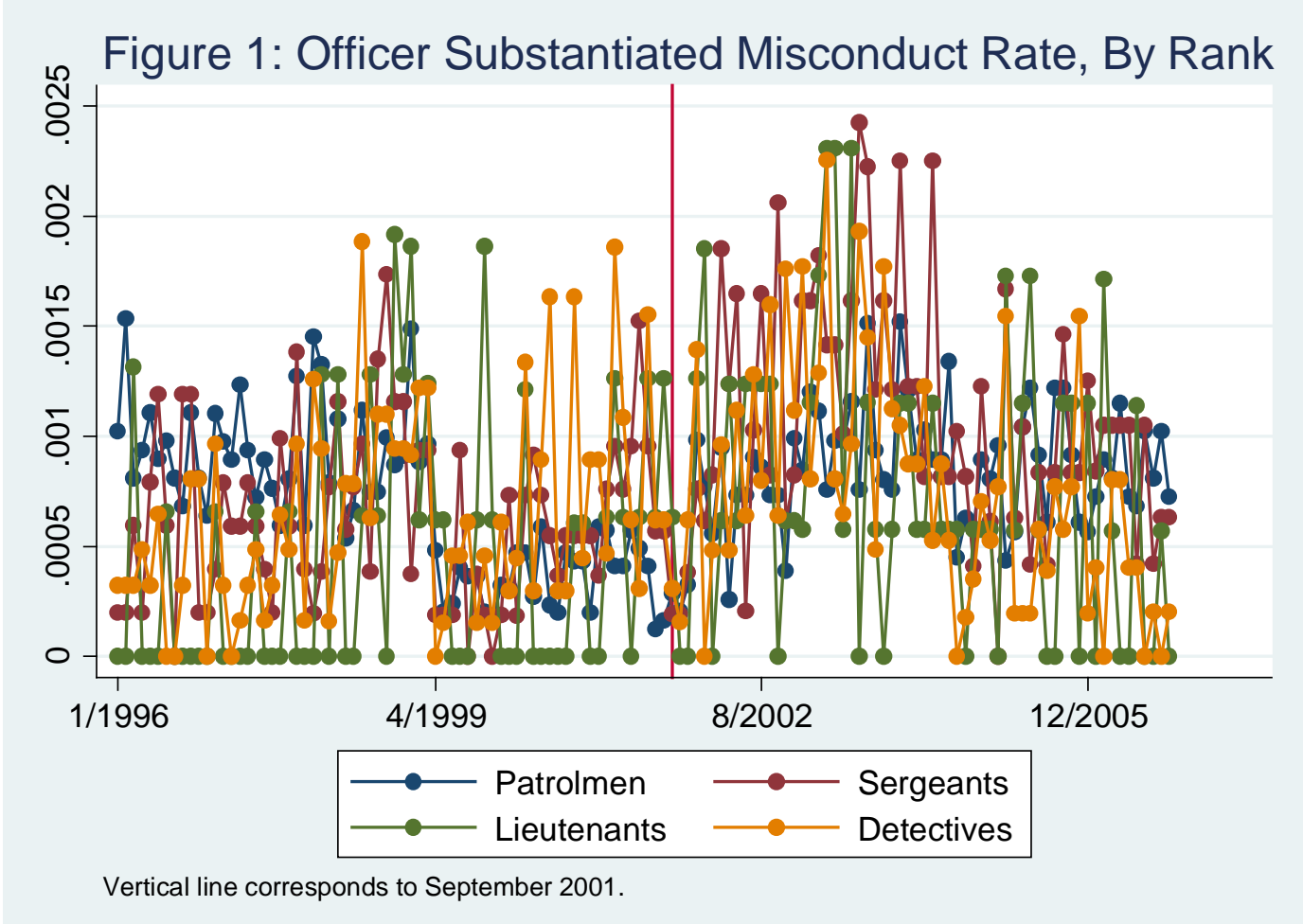

Figure 2: Officer Total Misconduct Rate, By Rank

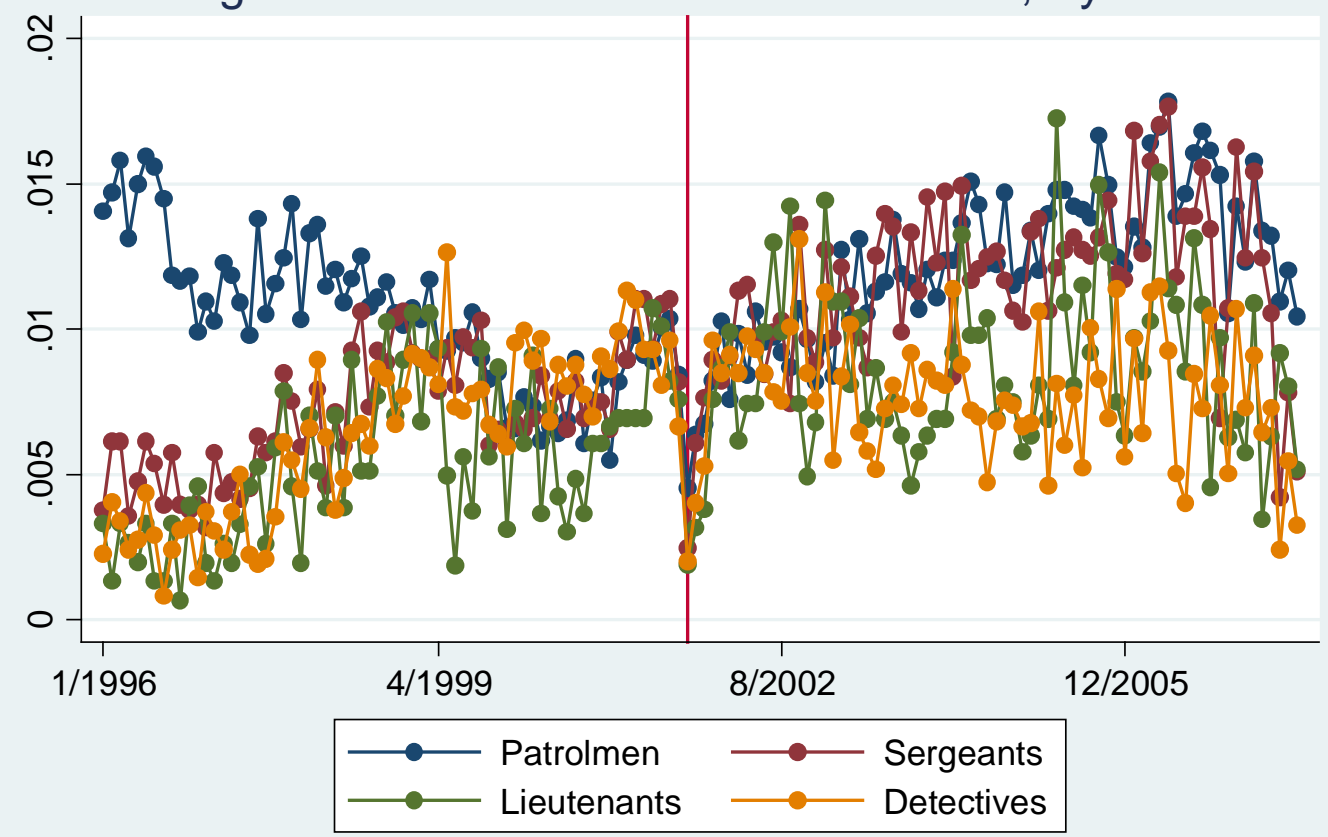

Vertical line corresponds to September 2001. 
Figure 3A: Patrolmen

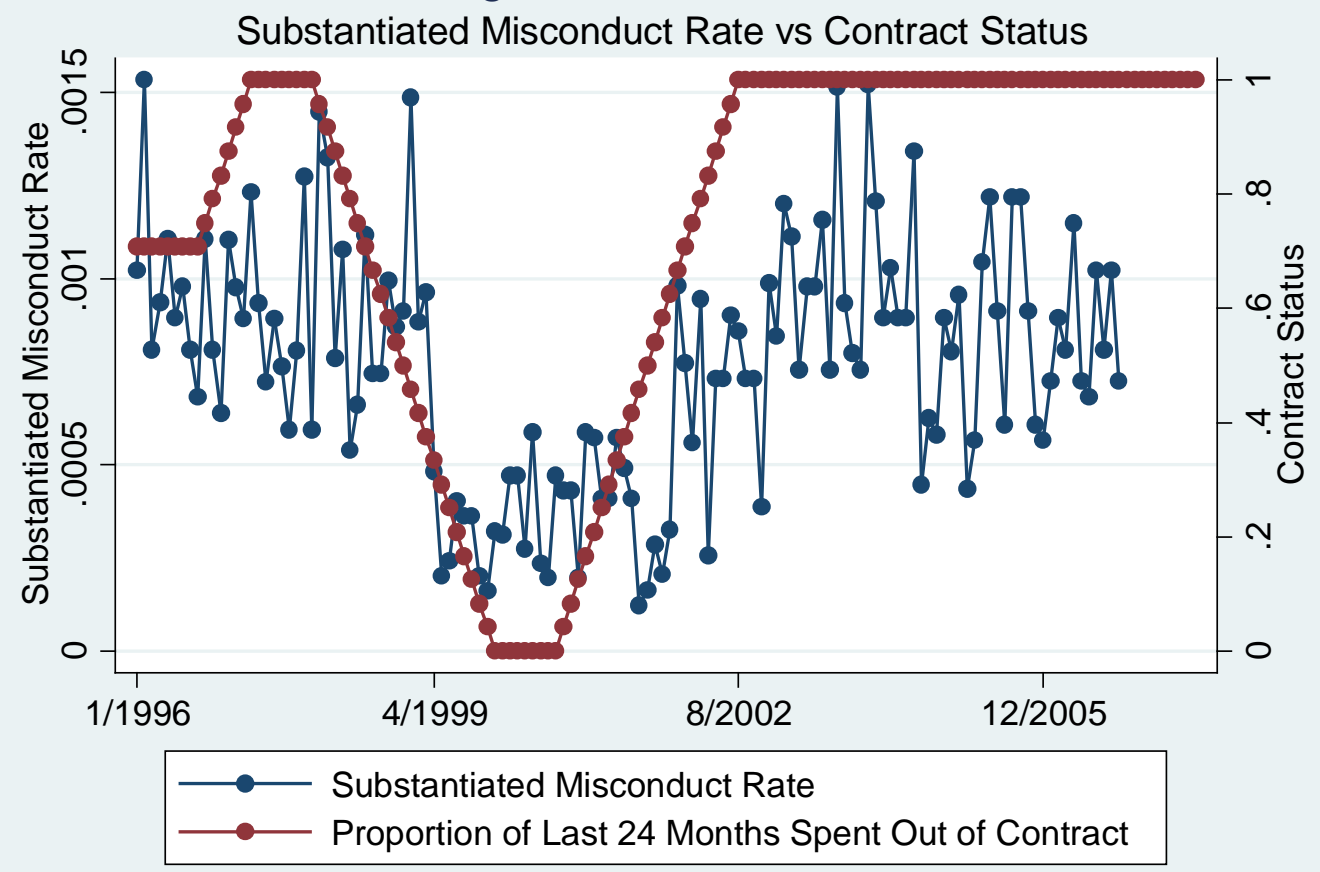

Figure 3B: Sergeants

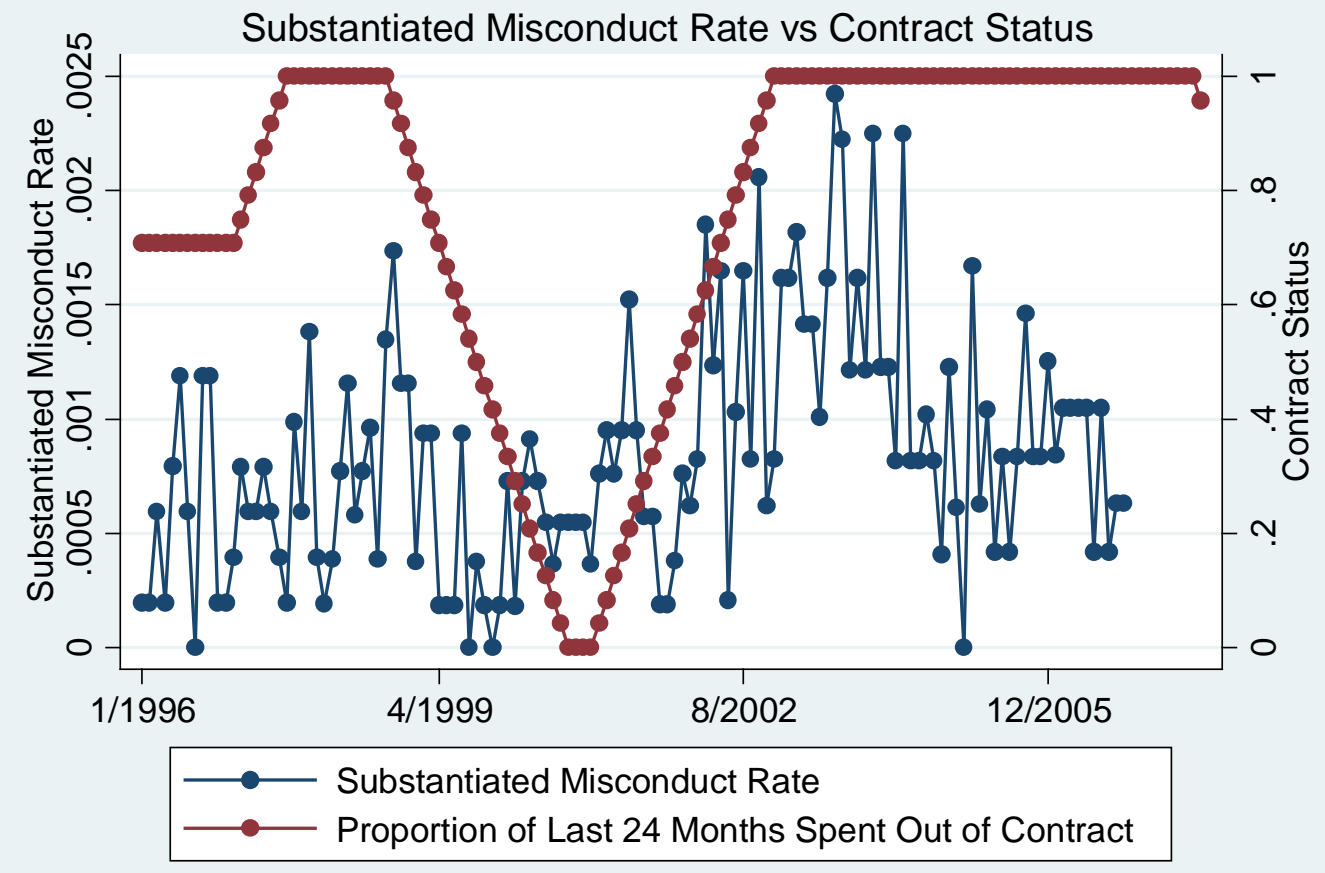


Figure 3C: Lieutenants

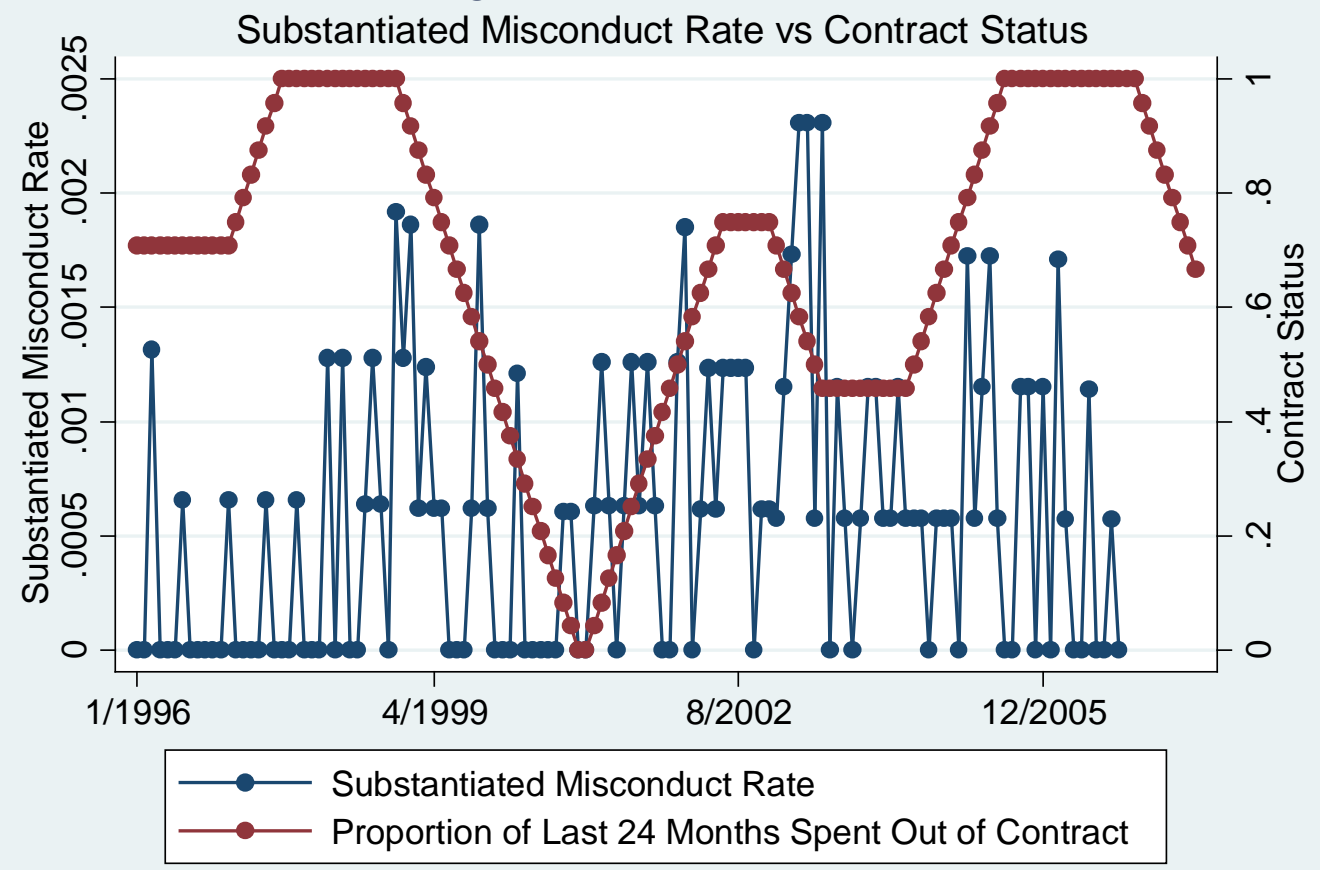

Figure 3D: Detectives

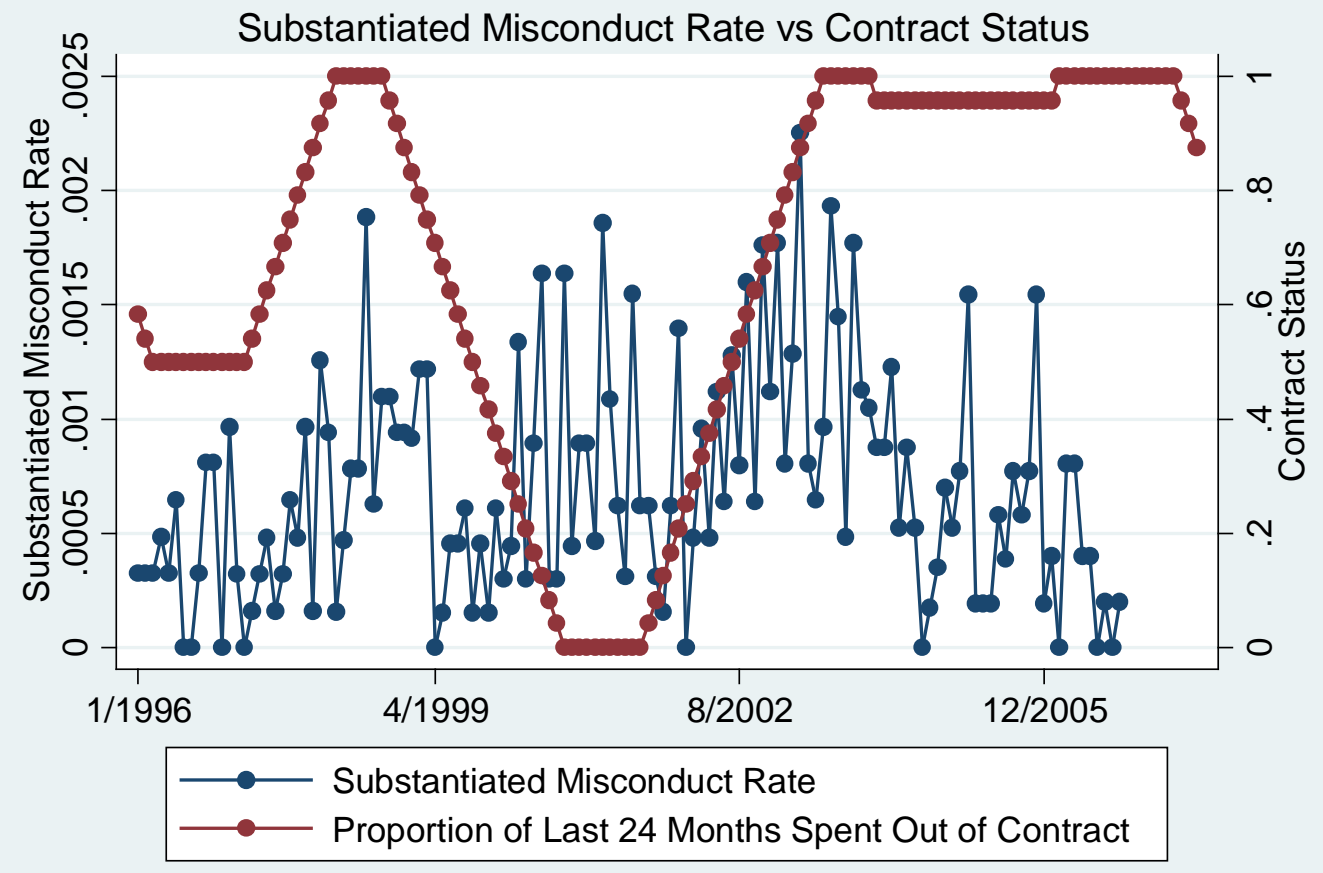


Figure 4A: Patrolmen

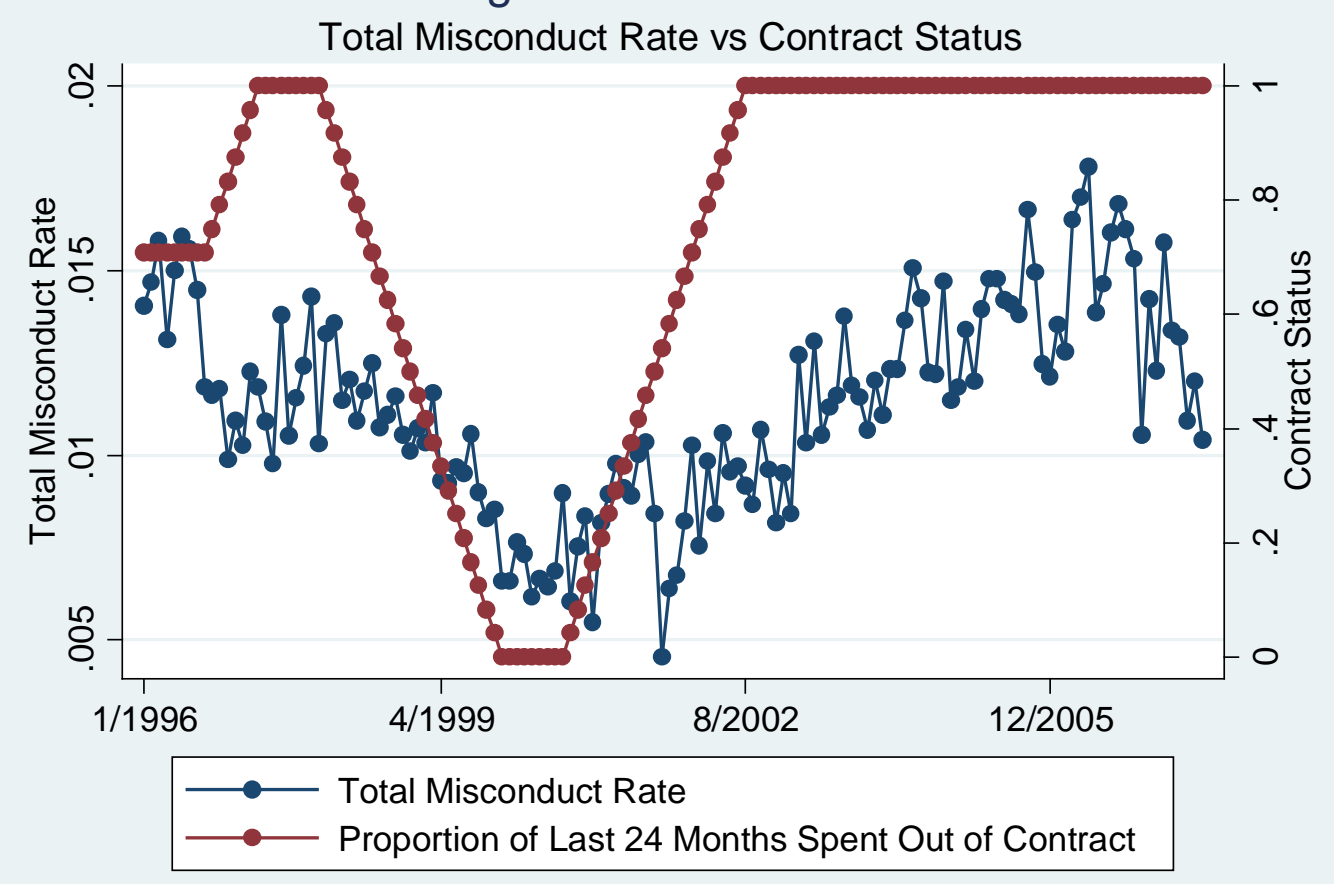

Figure 4B: Sergeants

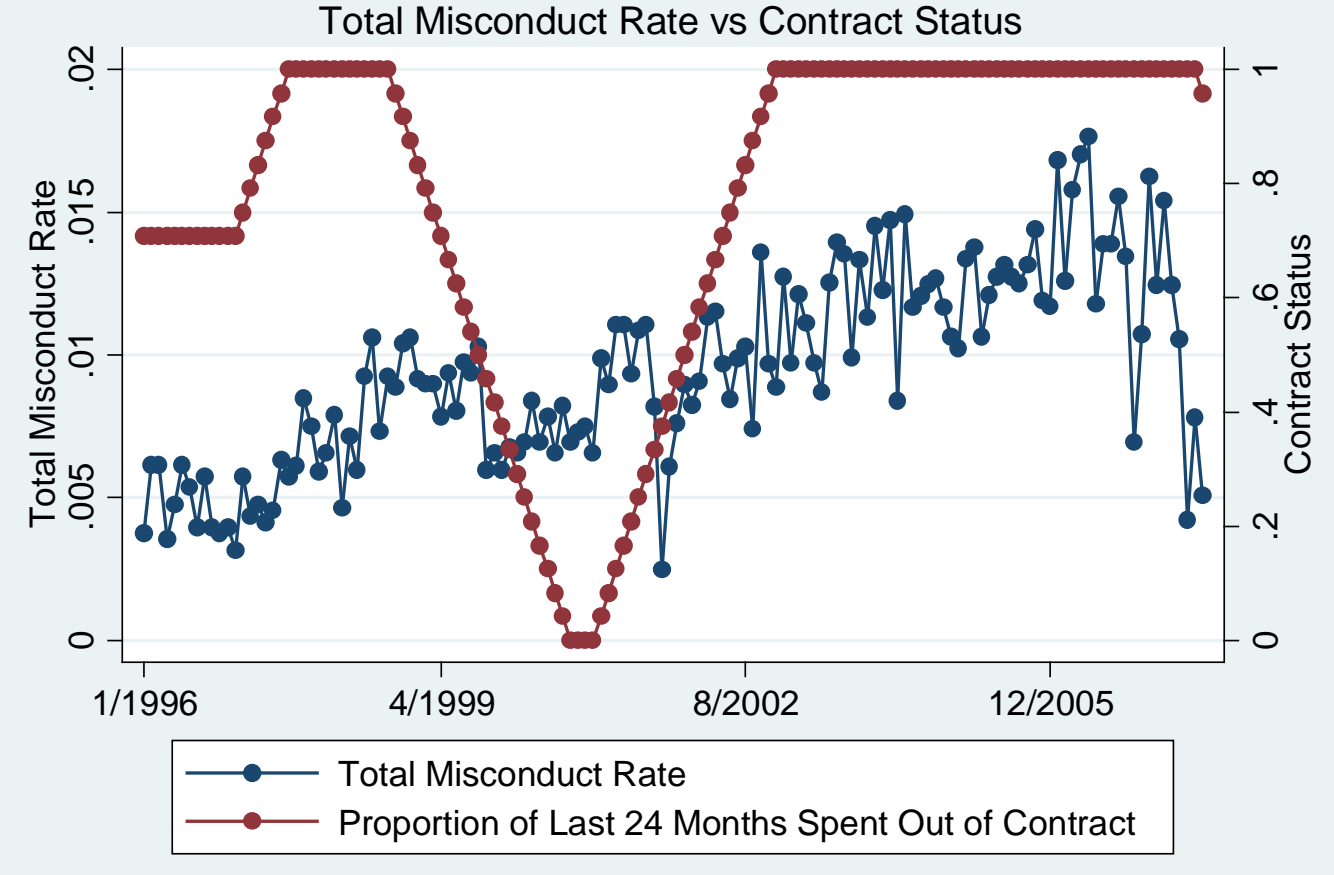


Figure 4C: Lieutenants

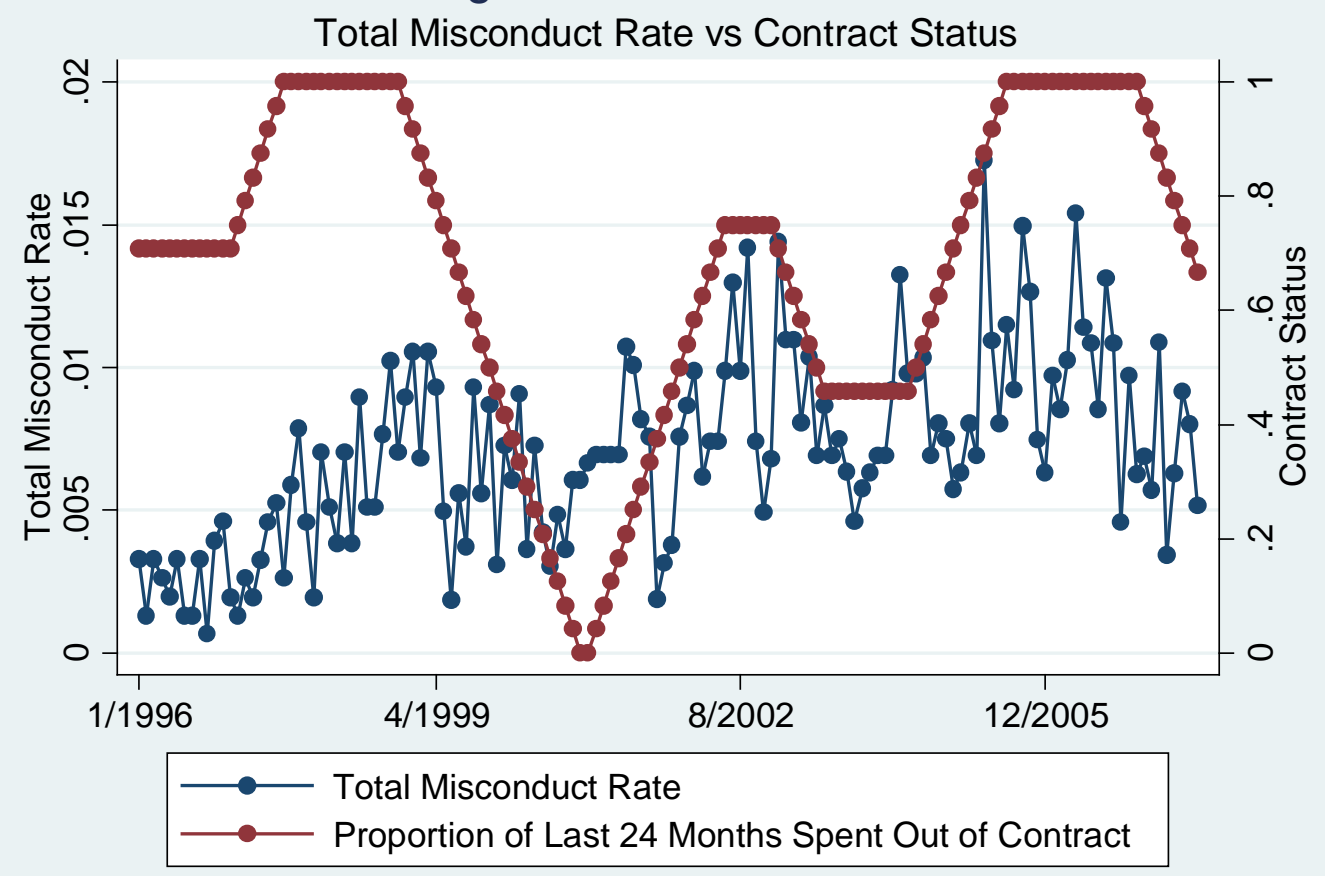

Figure 4D: Detectives

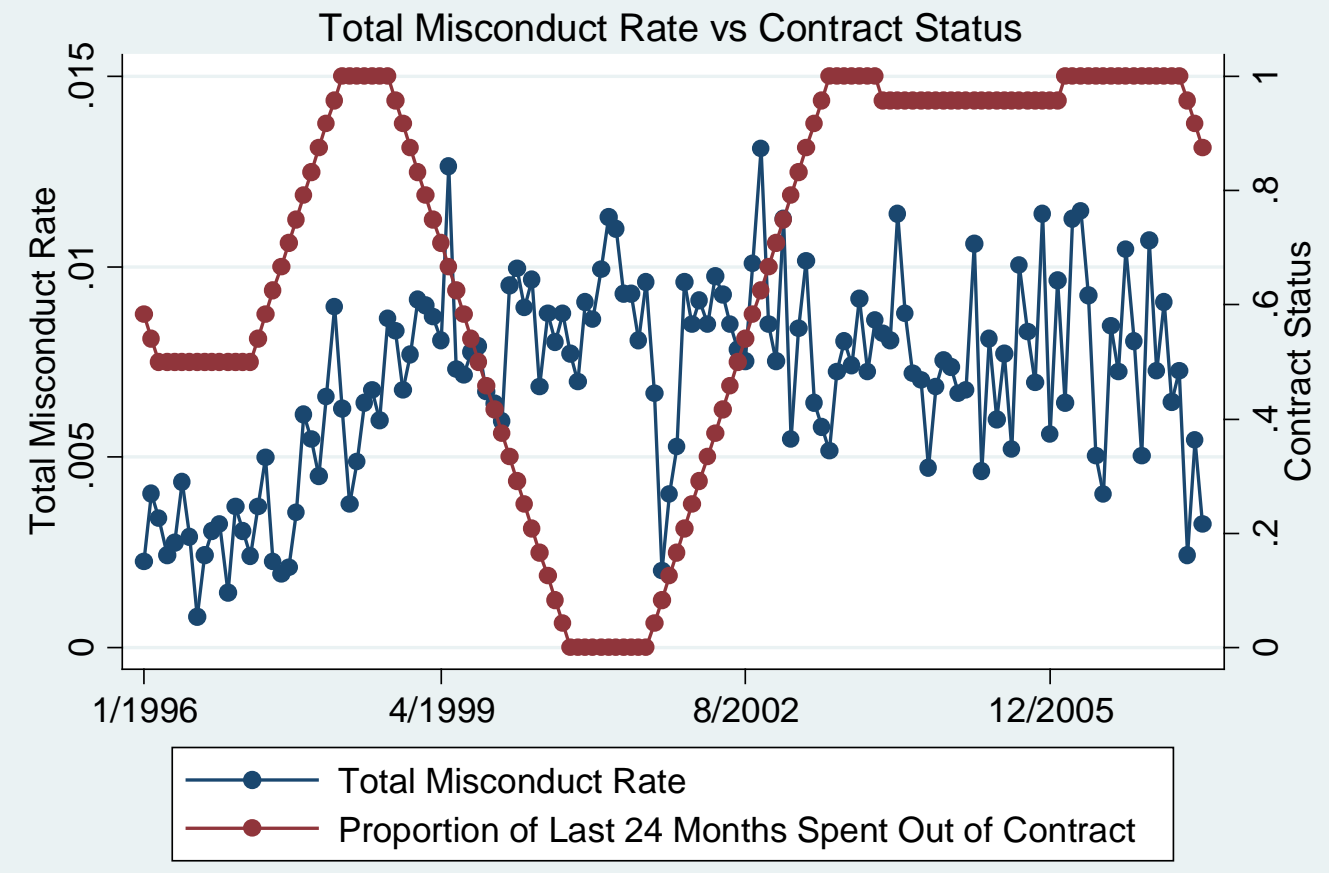


Figure 5: Patrolmen (PBA) and Firefighters (UFA) Contract Status Proportion of Last 24 Months Spent Out of Contract

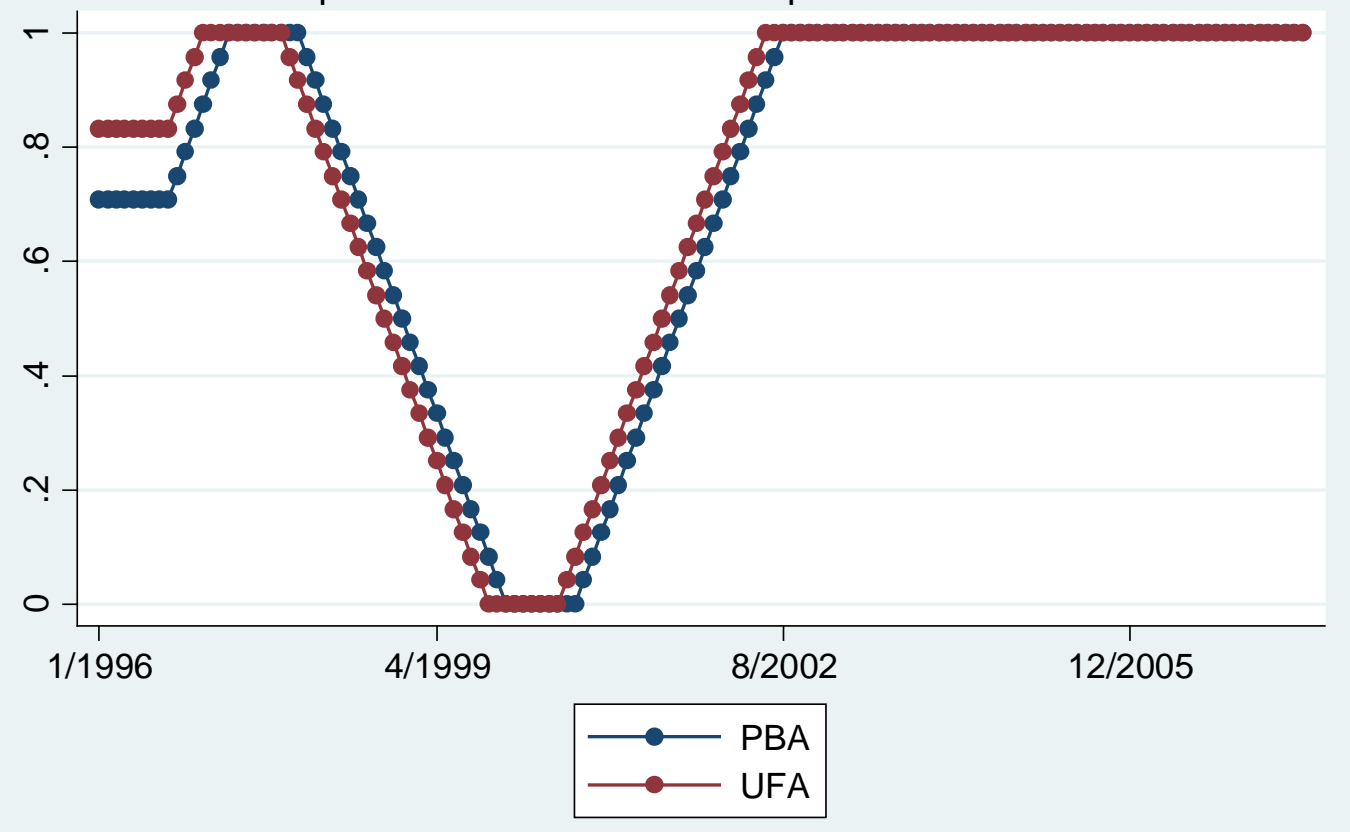




\begin{tabular}{|l|c|}
\hline \multicolumn{2}{|c|}{ Table 1. Misconduct Allegations and Incidents } \\
\hline Total Number of Allegations & 99,444 \\
\hline Total Number of Officer-Incidents & 51,632 \\
\hline \multicolumn{2}{|c|}{} \\
\hline Total Number of Substantiated Allegations & 6,533 \\
\hline Total Number of Substantiated Officer-Incidents & 3,654 \\
\hline Notes:
\end{tabular}

\begin{tabular}{|c|c|c|}
\hline \multicolumn{3}{|l|}{ Allegation Details } \\
\hline $\begin{array}{l}\text { Unsubstantiated or } \\
\text { Unfounded } \\
\text { (Officer Exonerated) }\end{array}$ & 58,325 & $58.7 \%$ \\
\hline $\begin{array}{l}\text { Complainant uncooperative, } \\
\text { unavailable, or withdrawn } \\
\text { complaint }\end{array}$ & 16,472 & $16.6 \%$ \\
\hline Substantiated Allegations & 6,533 & $6.6 \%$ \\
\hline Mediated or conciliated & 4,054 & $4.1 \%$ \\
\hline $\begin{array}{l}\text { Victim uncooperative or } \\
\text { unavailable }\end{array}$ & 1,760 & $1.8 \%$ \\
\hline $\begin{array}{l}\text { Internal Affairs Bureau } \\
\text { Referrals }\end{array}$ & 35 & $0 \%$ \\
\hline Other & 12,265 & $12.3 \%$ \\
\hline Total Allegations & 99,444 & \\
\hline \multicolumn{3}{|l|}{ Notes: } \\
\hline
\end{tabular}




\begin{tabular}{|c|c|}
\hline \multicolumn{2}{|l|}{ Excessive Force $(1,364$ allegations or $\mathbf{2 1 \%})$} \\
\hline Physical Force & $67.23 \%$ \\
\hline Gun Pointed & $6.01 \%$ \\
\hline Pepper Spray & $4.47 \%$ \\
\hline Nightstick as Club & $2.49 \%$ \\
\hline Radio as Club & $2.05 \%$ \\
\hline Hit Against Inanimate Object & $1.39 \%$ \\
\hline Chokehold & $1.25 \%$ \\
\hline Flashlight as Club & $1.03 \%$ \\
\hline Gun Club & $1.03 \%$ \\
\hline Gun Pointed / Gun Drawn & $0.88 \%$ \\
\hline Other Blunt Instrument & $0.66 \%$ \\
\hline Handcuffs Too Tight & $0.44 \%$ \\
\hline Vehicle & $0.37 \%$ \\
\hline Gun Fired & $0.37 \%$ \\
\hline Police Shield & $0.07 \%$ \\
\hline Other & $10.26 \%$ \\
\hline \multicolumn{2}{|l|}{ Abuse of Authority $(3,891$ allegations or $60 \%)$} \\
\hline Frisk and/or Search & $14.80 \%$ \\
\hline Question and/or Stop & $13.03 \%$ \\
\hline Refusal to Provide Name and/or Shield & $10.72 \%$ \\
\hline Threat of Arrest & $6.76 \%$ \\
\hline Vehicle Search & $6.27 \%$ \\
\hline Threat of Force & $6.27 \%$ \\
\hline Premises Entered or Searched & $5.68 \%$ \\
\hline Retaliatory Summons & $3.55 \%$ \\
\hline Search of Person & $3.19 \%$ \\
\hline Frisk & $3.08 \%$ \\
\hline Retaliatory Arrest & $3.01 \%$ \\
\hline Vehicle Stop & $2.57 \%$ \\
\hline Strip Search & $2.16 \%$ \\
\hline Seizure of Property & $1.70 \%$ \\
\hline Property Damaged & $1.62 \%$ \\
\hline Refusal to Process Civilian Complaint & $1.59 \%$ \\
\hline Refusal to Obtain Medical Treatment & $1.11 \%$ \\
\hline Threat to Damage/Seize Property & $0.75 \%$ \\
\hline Threat of Summons & $0.75 \%$ \\
\hline Gun Drawn & $0.33 \%$ \\
\hline Other & $11.08 \%$ \\
\hline \multicolumn{2}{|l|}{ Discourtesy $(1,101$ allegations or $\mathbf{1 7 \%})$} \\
\hline Discourteous Words & $86.65 \%$ \\
\hline Discourteous Actions & $4.90 \%$ \\
\hline Discourteous Demeanor or Tone & $2.72 \%$ \\
\hline Discourteous Gesture & $1.91 \%$ \\
\hline
\end{tabular}




\begin{tabular}{|l|l|}
\hline \multicolumn{2}{|l|}{ Table 3 Continued. Substantiated Misconduct Allegations-Type of Misconduct } \\
\hline \multicolumn{2}{|l|}{ Discourtesy (101 allegations) Continued } \\
\hline Other & $3.81 \%$ \\
\hline Offensive Language (169 allegations or 3\%) & \\
\hline Race & $57.99 \%$ \\
\hline Ethnicity & $14.20 \%$ \\
\hline Sexual Orientation & $7.69 \%$ \\
\hline Sex & $5.92 \%$ \\
\hline Physical Disability & $1.78 \%$ \\
\hline Other & $11.24 \%$ \\
\hline $\begin{array}{l}\text { Notes: The total number of substantiated allegations is 6,525. 8 allegations did not fall into the } \\
\text { excessive force, abuse of authority, discourtesy, or offensive language categories. }\end{array}$ \\
\hline
\end{tabular}




\begin{tabular}{|c|c|c|}
\hline & $\begin{array}{c}\text { Substantiated Misconduct } \\
\text { Officer-Incidents } \\
(1 / 1996-10 / 2006) \\
\end{array}$ & $\begin{array}{c}\text { Misconduct Officer-Incidents } \\
(1 / 1996-8 / 2007)\end{array}$ \\
\hline \multirow{3}{*}{$\begin{array}{l}\text { Average Number of Officer- } \\
\text { Incidents, Across All Ranks, Per } \\
\text { Month }\end{array}$} & 6.85 & 92.2 \\
\hline & [7.83] & [107.37] \\
\hline & $\mathrm{N}=520$ & $\mathrm{~N}=560$ \\
\hline
\end{tabular}

\begin{tabular}{|c|c|c|}
\hline \multicolumn{3}{|c|}{ Table 5. Monthly Misconduct Rate, By Rank } \\
\hline $\begin{array}{l}\text { Average Number of } \\
\text { Officer-Incidents, By Rank, Per Month }\end{array}$ & $\begin{array}{c}\text { Substantiated } \\
\text { Misconduct Officer- } \\
\text { Incidents } \\
(1 / 1996-10 / 2006)\end{array}$ & $\begin{array}{c}\text { Misconduct Officer- } \\
\text { Incidents } \\
(1 / 1996-8 / 2007)\end{array}$ \\
\hline Patrolmen & $\begin{array}{l}17.95 \\
{[7.52]}\end{array}$ & $\begin{array}{l}267.66 \\
{[61.07]}\end{array}$ \\
\hline Detectives & $\begin{array}{c}4.29 \\
{[3.17]}\end{array}$ & $\begin{array}{c}42.3 \\
{[16.35]}\end{array}$ \\
\hline Sergeant & $\begin{array}{c}4.21 \\
{[2.56]}\end{array}$ & $\begin{array}{c}47.1 \\
{[15.73]}\end{array}$ \\
\hline Lieutenant & $\begin{array}{c}0.97 \\
{[1.04]}\end{array}$ & $\begin{array}{l}11.74 \\
{[5.74]}\end{array}$ \\
\hline & $\mathrm{N}=130$ & $\mathrm{~N}=140$ \\
\hline Average Police Force Size, By Rank, Per Month & \multirow{2}{*}{\multicolumn{2}{|c|}{$\begin{array}{c}23,677.57 \\
{[906.88]}\end{array}$}} \\
\hline Patrolmen & & \\
\hline Detectives & \multicolumn{2}{|c|}{$\begin{array}{l}6,012.89 \\
{[582.24]}\end{array}$} \\
\hline Sergeant & \multicolumn{2}{|c|}{$\begin{array}{l}5,037.83 \\
{[231.49]}\end{array}$} \\
\hline Lieutenant & \multicolumn{2}{|c|}{$\begin{array}{c}1,646.14 \\
{[85.82]}\end{array}$} \\
\hline & \multicolumn{2}{|c|}{$\mathrm{N}=140$} \\
\hline \multicolumn{3}{|l|}{ Average Misconduct Rate by Rank, Per Month } \\
\hline Patrolmen & $\begin{array}{c}0.00076 \\
{[0.00032]}\end{array}$ & $\begin{array}{c}0.011 \\
{[0.003]}\end{array}$ \\
\hline Detective & $\begin{array}{c}0.00069 \\
{[0.00050]}\end{array}$ & $\begin{array}{c}0.007 \\
{[0.003]}\end{array}$ \\
\hline Sergeant & $\begin{array}{c}0.00082 \\
{[0.00050]}\end{array}$ & $\begin{array}{c}0.009 \\
{[0.003]}\end{array}$ \\
\hline Lieutenant & $\begin{array}{c}0.00058 \\
{[0.00061]}\end{array}$ & $\begin{array}{c}0.007 \\
{[0.003]}\end{array}$ \\
\hline & $\mathrm{N}=130$ & $\mathrm{~N}=140$ \\
\hline
\end{tabular}




\begin{tabular}{|c|c|c|}
\hline \multicolumn{3}{|c|}{$\begin{array}{l}\text { Table 6. Effect of Contract Status on Misconduct } \\
\text { Poisson Model } \\
\text { (Police Officers are the Omitted Category) }\end{array}$} \\
\hline & $\begin{array}{l}\text { Substantiated } \\
\text { Misconduct }\end{array}$ & $\begin{array}{l}\text { Total } \\
\text { Misconduct }\end{array}$ \\
\hline $\begin{array}{l}\text { Proportion of Last } 24 \text { Months Spent Out of } \\
\text { Contract }\end{array}$ & $\begin{array}{c}0.9254 * * * \\
(0.0753)\end{array}$ & $\begin{array}{c}0.3529 * * * \\
(0.0503)\end{array}$ \\
\hline Felony Arrests (in Thousands) & $\begin{array}{c}0.1694 * * * \\
(0.0337)\end{array}$ & $\begin{array}{c}0.0945^{* * *} \\
(0.0080)\end{array}$ \\
\hline September $11^{\text {th }}$ Indicator & $\begin{array}{l}-0.0685 \\
(0.2153)\end{array}$ & $\begin{array}{c}-0.1969 * * * \\
(0.0477)\end{array}$ \\
\hline Parking Tickets (in Hundreds of Thousands) & $\begin{array}{l}-0.0086 \\
(0.0914)\end{array}$ & $\begin{array}{c}0.0839 * * * \\
(0.0170)\end{array}$ \\
\hline \multicolumn{3}{|l|}{ Seasons (relative to Fall) } \\
\hline Winter & $\begin{array}{c}0.1725 \\
(0.1105)\end{array}$ & $\begin{array}{c}-0.0495^{* * *} \\
(0.0191)\end{array}$ \\
\hline Spring & $\begin{array}{c}0.0350 \\
(0.0737)\end{array}$ & $\begin{array}{l}-0.0134 \\
(0.0103)\end{array}$ \\
\hline Summer & $\begin{array}{l}-0.0735 \\
(0.0630)\end{array}$ & $\begin{array}{l}-0.0263 \\
(0.0333)\end{array}$ \\
\hline \multicolumn{3}{|l|}{ Rank (relative to Patrolmen) } \\
\hline Sergeants & $\begin{array}{c}-0.5299 * * * \\
(0.0018)\end{array}$ & $\begin{array}{c}-1.0434 * * * \\
(0.0011)\end{array}$ \\
\hline Lieutenants & $\begin{array}{c}-1.7290 * * * \\
(0.0018)\end{array}$ & $\begin{array}{c}-1.6609 * * * \\
(0.0011)\end{array}$ \\
\hline Detectives & $\begin{array}{c}-0.7531^{* * *} \\
(0.0164)\end{array}$ & $\begin{array}{c}-1.5221^{* * *} \\
(0.0110)\end{array}$ \\
\hline Year Fixed Effects & $\mathrm{Y}$ & $\mathrm{Y}$ \\
\hline Rank X Year Fixed Effects & $\mathrm{Y}$ & $\mathrm{Y}$ \\
\hline Constant & Y & $\mathrm{Y}$ \\
\hline $\mathrm{N}$ & 520 & 552 \\
\hline $\mathrm{R} 2$ & & \\
\hline \multicolumn{3}{|l|}{$\begin{array}{l}\text { Notes: }{ }^{*} \mathrm{p}<0.10 ; * * \mathrm{p}<0.05 ; * * * \mathrm{p}<0.01 \\
\text { Standard errors are clustered at the rank level. } \\
\text { Ranks size is used as the exposure variable. }\end{array}$} \\
\hline
\end{tabular}




\begin{tabular}{|c|c|c|c|c|}
\hline \multicolumn{5}{|c|}{$\begin{array}{l}\text { Table 7. Effect of Contract Status on the Type of Substantiated Misconduct } \\
\text { Poisson Model } \\
\text { (Police Officers are the Omitted Category) }\end{array}$} \\
\hline & $\begin{array}{l}\text { Excessive } \\
\text { Force }\end{array}$ & Abuse of Authority & Discourtesy & Language \\
\hline $\begin{array}{l}\text { Proportion of Last } 24 \text { Months } \\
\text { Spent Out of Contract }\end{array}$ & $\begin{array}{c}0.4774 \\
(0.2952)\end{array}$ & $\begin{array}{c}1.0407^{* * *} \\
(0.1713)\end{array}$ & $\begin{array}{c}1.6276 * * * \\
(0.3826)\end{array}$ & $\begin{array}{l}-0.8003 \\
(0.5891)\end{array}$ \\
\hline Felony Arrests (in Thousands) & $\begin{array}{c}0.1622^{* * *} \\
(0.0230) \\
\end{array}$ & $\begin{array}{l}0.1743^{* *} \\
(0.0727)\end{array}$ & $\begin{array}{c}0.2111 * * \\
(0.1017)\end{array}$ & $\begin{array}{c}-0.3776 * * * \\
(0.0744)\end{array}$ \\
\hline September $11^{\text {th }}$ Indicator & $\begin{array}{c}0.3785 \\
(0.1939) \\
\end{array}$ & $\begin{array}{c}-0.4445^{* * *} \\
(0.1510) \\
\end{array}$ & $\begin{array}{c}0.2482 \\
(0.2162) \\
\end{array}$ & $\begin{array}{c}0.4512 \\
(0.4606) \\
\end{array}$ \\
\hline $\begin{array}{l}\text { Parking Tickets (in Hundreds } \\
\text { of Thousands) }\end{array}$ & $\begin{array}{c}0.0249 \\
(0.0856)\end{array}$ & $\begin{array}{c}0.0054 \\
(0.1106)\end{array}$ & $\begin{array}{l}-0.1032 \\
(0.1306)\end{array}$ & $\begin{array}{c}0.4941 * * * \\
(0.1800)\end{array}$ \\
\hline \multicolumn{5}{|l|}{ Seasons (relative to Fall) } \\
\hline Winter & $\begin{array}{c}0.0462 \\
(0.1250)\end{array}$ & $\begin{array}{c}0.2524 \\
(0.1430)\end{array}$ & $\begin{array}{l}0.1032 * * \\
(0.0417)\end{array}$ & $\begin{array}{c}-0.7306^{* * *} \\
(0.2464)\end{array}$ \\
\hline Spring & $\begin{array}{c}0.0673 \\
(0.1424) \\
\end{array}$ & $\begin{array}{c}0.0159 \\
(0.0640)\end{array}$ & $\begin{array}{c}0.0692 \\
(0.1571) \\
\end{array}$ & $\begin{array}{c}-0.2517^{* * *} \\
(0.0840) \\
\end{array}$ \\
\hline Summer & $\begin{array}{l}-0.0307 \\
(0.0595)\end{array}$ & $\begin{array}{c}-0.1293^{* *} \\
(0.0552)\end{array}$ & $\begin{array}{c}0.1265 \\
(0.0771)\end{array}$ & $\begin{array}{c}-0.2834^{* *} \\
(0.1276)\end{array}$ \\
\hline \multicolumn{5}{|l|}{ Rank (relative to Patrolmen) } \\
\hline Sergeants & $\begin{array}{c}-0.8577^{* * *} \\
(0.0055)\end{array}$ & $\begin{array}{c}-0.1333 * * * \\
(0.0041)\end{array}$ & $\begin{array}{c}-1.5441^{* * *} \\
(0.0066)\end{array}$ & $\begin{array}{c}-16.4901^{* * *} \\
(1.1484)\end{array}$ \\
\hline Lieutenants & $\begin{array}{c}-1.1252^{* * *} \\
(0.0055) \\
\end{array}$ & $\begin{array}{c}-15.0297 * * * \\
(1.1555)\end{array}$ & $\begin{array}{c}-16.0522 * * * \\
(1.1517)\end{array}$ & $\begin{array}{c}-15.2913^{* * *} \\
(1.1548)\end{array}$ \\
\hline Detectives & $\begin{array}{c}-0.9681 * * * \\
(0.0641)\end{array}$ & $\begin{array}{c}-0.3599 * * * \\
(0.0379)\end{array}$ & $\begin{array}{c}-1.4259 * * * \\
(0.0836)\end{array}$ & $\begin{array}{c}0.4613 * * * \\
(0.1308)\end{array}$ \\
\hline Year Fixed Effects & $\mathrm{Y}$ & $\mathrm{Y}$ & $\mathrm{Y}$ & $\mathrm{Y}$ \\
\hline Rank X Year Fixed Effects & $\mathrm{Y}$ & $\mathrm{Y}$ & $\mathrm{Y}$ & $\mathrm{Y}$ \\
\hline Constant & $\mathrm{Y}$ & $\mathrm{Y}$ & $\mathrm{Y}$ & $\mathrm{Y}$ \\
\hline $\mathrm{N}$ & 520 & 520 & 520 & 520 \\
\hline $\mathrm{R} 2$ & & & & \\
\hline \multicolumn{5}{|c|}{$\begin{array}{l}\text { Notes: }+p<0.10 ;{ }^{*} p<0.05 ;{ }^{* *} p<0.01 ;{ }^{* * *} p<0.001 \\
\text { Standard errors are clustered at the rank level. } \\
\text { Rank size is used as the exposure variable. }\end{array}$} \\
\hline
\end{tabular}




\begin{tabular}{|c|c|c|}
\hline \multicolumn{3}{|c|}{$\begin{array}{l}\text { Table 9. Robustness Check: Log-Linear Model } \\
\text { (Police Officers are the Omitted Category) }\end{array}$} \\
\hline & $\begin{array}{l}\text { LN(Substantiated } \\
\text { Misconduct Rate) }\end{array}$ & $\begin{array}{c}\text { LN(Total } \\
\text { Misconduct Rate) }\end{array}$ \\
\hline $\begin{array}{l}\text { Proportion of Last } 24 \text { Months Spent Out of } \\
\text { Contract }\end{array}$ & $\begin{array}{c}0.5761^{* *} \\
(0.1356)\end{array}$ & $\begin{array}{l}0.658 * * \\
(0.1917)\end{array}$ \\
\hline Felony Arrests (in Thousands) & $\begin{array}{l}0.1351^{*} \\
(0.0548)\end{array}$ & $\begin{array}{c}0.0956 * * * \\
(0.0170)\end{array}$ \\
\hline September $11^{\text {th }}$ Indicator & $\begin{array}{l}-0.0870 \\
(0.2313)\end{array}$ & $\begin{array}{l}-0.3708^{*} \\
(0.1199)\end{array}$ \\
\hline Parking Tickets (in Hundreds of Thousands) & $\begin{array}{c}0.1190 \\
(0.1233)\end{array}$ & $\begin{array}{l}0.1731^{* *} \\
(0.0389)\end{array}$ \\
\hline \multicolumn{3}{|l|}{ Seasons (relative to Fall) } \\
\hline Winter & $\begin{array}{c}0.1021 \\
(0.1305)\end{array}$ & $\begin{array}{l}-0.0506^{*} \\
(0.0195)\end{array}$ \\
\hline Spring & $\begin{array}{l}-0.0229 \\
(0.1223)\end{array}$ & $\begin{array}{c}-0.0605^{* *} \\
(0.0186)\end{array}$ \\
\hline Summer & $\begin{array}{l}-0.0793 \\
(0.0588)\end{array}$ & $\begin{array}{l}-0.0978 \\
(0.0655)\end{array}$ \\
\hline \multicolumn{3}{|l|}{ Rank (relative to Patrolmen) } \\
\hline Sergeants & $\begin{array}{c}-0.7239 * * * \\
(0.0060)\end{array}$ & $\begin{array}{c}-1.0490 * * * \\
(0.0040)\end{array}$ \\
\hline Lieutenants & $\begin{array}{c}0.0357 \\
(0.0211)\end{array}$ & $\begin{array}{c}-1.7810 * * * \\
(0.0040)\end{array}$ \\
\hline Detectives & $\begin{array}{c}-0.6019 * * * \\
(0.0387) \\
\end{array}$ & $\begin{array}{c}-1.5262^{* * *} \\
(0.0419) \\
\end{array}$ \\
\hline Year Fixed Effects & $\mathrm{Y}$ & $\mathrm{Y}$ \\
\hline Rank X Year Fixed Effects & $\mathrm{Y}$ & $\mathrm{Y}$ \\
\hline Constant & $\mathrm{Y}$ & $\mathrm{Y}$ \\
\hline $\mathrm{N}$ & $451^{¥}$ & 552 \\
\hline R2 & & \\
\hline \multicolumn{3}{|c|}{$\begin{array}{l}\text { Notes: }{ }^{*} p<0.10 ;{ }^{*} p<0.05 ;{ }^{* *} p<0.01 \\
\text { Standard errors are clustered at the rank level. } \\
{ }^{*} 69 \text { rank-month observations with zero substantiated misconduct are dropped from the original } 520 \\
\text { observations due to the log transformation. Specifications using LN(Substantiated Misconduct+0.1) } \\
\text { and LN(Substantiated Misconduct }+0.01 \text { ) as the dependent variable yielded similar results. }\end{array}$} \\
\hline
\end{tabular}




\begin{tabular}{|c|c|c|}
\hline \multicolumn{3}{|c|}{$\begin{array}{l}\text { Table 10. Robustness Check: Testing Different Time Horizon Windows } \\
\text { (Police Officers are the Omitted Category) }\end{array}$} \\
\hline & $\begin{array}{l}\text { Substantiated } \\
\text { Misconduct Rate }\end{array}$ & $\begin{array}{c}\text { Total } \\
\text { Misconduct Rate }\end{array}$ \\
\hline $\begin{array}{l}\text { Proportion of Last } 6 \text { months Spent Out of } \\
\text { Contact }\end{array}$ & $\begin{array}{c}0.1330 * * * \\
(0.0440)\end{array}$ & $\begin{array}{c}0.0515 \\
(0.0953)\end{array}$ \\
\hline ... Last 12 Months & $\begin{array}{c}0.1969 \\
(0.3135) \\
\end{array}$ & $\begin{array}{c}0.1045^{* * *} \\
(0.0303)\end{array}$ \\
\hline ... Last 18 Months & $\begin{array}{l}0.5710^{* *} \\
(0.2903)\end{array}$ & $\begin{array}{c}0.1284 \\
(0.1051)\end{array}$ \\
\hline ... Last 24 Months & $\begin{array}{c}0.9254 * * * \\
(0.0753)\end{array}$ & $\begin{array}{c}0.3529 * * * \\
(0.0503)\end{array}$ \\
\hline ... Last 36 Months & $\begin{array}{c}1.1957^{* * *} \\
(0.0764)\end{array}$ & $\begin{array}{c}0.5539 * * * \\
(0.0154) \\
\end{array}$ \\
\hline ... Last 48 Months & $\begin{array}{c}0.1091 \\
(0.5060)\end{array}$ & $\begin{array}{c}0.4886^{* *} \\
(0.2137)\end{array}$ \\
\hline $\mathrm{N}$ & 520 & 552 \\
\hline \multicolumn{3}{|c|}{$\begin{array}{l}\text { Notes: }{ }^{*} \mathrm{p}<0.10 ;{ }^{* *} \mathrm{p}<0.05 ; * * * \mathrm{p}<0.01 \\
\text { Standard errors are clustered at the rank level. }\end{array}$} \\
\hline
\end{tabular}




\begin{tabular}{|c|c|c|c|}
\hline & $\begin{array}{l}\text { Number of Out of } \\
\text { Contract Spells }\end{array}$ & Out of Contract Spells & $\begin{array}{l}\text { Median Number of } \\
\text { Months Out Of Contract }\end{array}$ \\
\hline Patrolmen & 7 & $\begin{array}{ll}\text { - } & 7 / 80-2 / 81 \text { (8 Months) } \\
\text { - } & 7 / 82-4 / 83 \text { (10 Months) } \\
\text { - } & 7 / 84-5 / 86 \text { (23 Months) } \\
\text { - } & 7 / 87-7 / 89 \text { ( } 25 \text { Months) } \\
\text { - } & 7 / 90-8 / 94 \text { (51 Months) } \\
\text { - } & 4 / 95-11 / 97 \text { (32 Months) } \\
\text { - } & 8 / 00-8 / 08 \text { (97 Months) } \\
\end{array}$ & 25 \\
\hline Sergeants & 7 & $\begin{array}{ll}\text { - } & 7 / 80-12 / 81 \text { (18 Months) } \\
\text { - } & 7 / 82-10 / 83 \text { (16 Months) } \\
\text { - } & 7 / 84-12 / 86 \text { (30 Months) } \\
\text { - } & 7 / 87-1 / 92 \text { (55 Months) } \\
\text { - } & 2 / 92-12 / 94 \text { (35 Months) } \\
\text { - } & 8 / 95-8 / 98 \text { (37 Months) } \\
\text { - } & 12 / 00-6 / 07 \text { (79 Months) } \\
\end{array}$ & 35 \\
\hline Lieutenants & 8 & $\begin{array}{ll}\text { - } & 7 / 80-11 / 83 \text { (41 Months) } \\
\text { - } & 7 / 84-6 / 86 \text { (24 Months) } \\
\text { - } & 7 / 87-9 / 90 \text { (39 Months) } \\
\text { - } & 11 / 90-12 / 94 \text { (50 Months) } \\
\text { - } & 8 / 95-10 / 98 \text { (34 Months) } \\
\text { - } & 12 / 00-5 / 02 \text { (18 Months) } \\
\text { - } & 7 / 03-11 / 06 \text { (41 Months) } \\
\text { - } & 9 / 07-1 / 09 \text { (17 Months) }\end{array}$ & 36.5 \\
\hline Detectives & 8 & $\begin{array}{ll} & 7 / 80-12 / 81 \text { (18 Months) } \\
\text { - } & 7 / 82-6 / 83 \text { (12 Months) } \\
\text { - } & 7 / 84-2 / 87 \text { (32 Months) } \\
\text { - } & 7 / 87-8 / 90 \text { (38 Months) } \\
\text { - } & 7 / 91-2 / 95 \text { (44 Months) } \\
\text { - } & 3 / 96-8 / 98 \text { (30 Months) } \\
\text { - } & 7 / 01-12 / 03 \text { (30 Months) } \\
\text { - } & 2 / 04-4 / 07 \text { (39 Months) }\end{array}$ & 31 \\
\hline
\end{tabular}




\begin{tabular}{|c|c|c|c|c|c|c|c|}
\hline \multicolumn{8}{|c|}{ Appendix Table A-Contract Dates and Status } \\
\hline Rank & Union & $\begin{array}{l}\text { Contract } \\
\text { Number }\end{array}$ & Contract Dates & $\begin{array}{l}\text { Date Contract Was } \\
\text { Signed by Labor } \\
\text { Relations } \\
\text { Commissioner }\end{array}$ & $\begin{array}{l}\text { Date Contract Was } \\
\text { Registered with } \\
\text { City }\end{array}$ & $\begin{array}{l}\text { Dates Out of } \\
\text { Contract }\end{array}$ & Dates In Contract \\
\hline \multirow[t]{5}{*}{ Patrolmen } & \multirow{5}{*}{$\begin{array}{l}\text { Patrolmen's } \\
\text { Benevolent } \\
\text { Association }\end{array}$} & 1 & $\begin{array}{l}4 / 1 / 1995- \\
7 / 31 / 2000\end{array}$ & 12/12/1997 & 12/18/1997 & $\begin{array}{l}4 / 1 / 1995- \\
12 / 11 / 1997\end{array}$ & $\begin{array}{l}\text { 12/12/1997- } \\
7 / 31 / 2000\end{array}$ \\
\hline & & 2 & $\begin{array}{l}8 / 1 / 2000- \\
7 / 31 / 2002\end{array}$ & Blank & $\begin{array}{l}\text { 9/4/2002 via } \\
\text { Arbitration }\end{array}$ & $\begin{array}{l}\text { 8/1/2000- } \\
7 / 31 / 2002\end{array}$ & \\
\hline & & 3 & $\begin{array}{l}8 / 1 / 2002- \\
7 / 31 / 2004 \\
\end{array}$ & $6 / 28 / 2006$ & $7 / 24 / 2006$ & $\begin{array}{l}8 / 1 / 2002- \\
7 / 31 / 2004 \\
\end{array}$ & \\
\hline & & 4 & $\begin{array}{l}\text { 8/1/2004- } \\
7 / 31 / 2006\end{array}$ & Blank & $\begin{array}{l}\text { 5/22/2008 via } \\
\text { Arbitration }\end{array}$ & $\begin{array}{l}\text { 8/1/2004- } \\
7 / 31 / 2006\end{array}$ & \\
\hline & & 5 & $\begin{array}{l}8 / 1 / 2006- \\
7 / 31 / 2010\end{array}$ & $8 / 21 / 2008$ & Blank & $\begin{array}{l}8 / 1 / 2006- \\
8 / 20 / 2008\end{array}$ & $\begin{array}{l}8 / 21 / 2008- \\
7 / 31 / 2010\end{array}$ \\
\hline \multirow[t]{4}{*}{ Sergeants } & \multirow{4}{*}{$\begin{array}{l}\text { Sergeants } \\
\text { Benevolent } \\
\text { Association }\end{array}$} & 1 & $\begin{array}{l}8 / 1 / 1995- \\
11 / 30 / 2000\end{array}$ & $8 / 26 / 1998$ & $8 / 26 / 1998$ & $\begin{array}{l}8 / 1 / 1995- \\
8 / 25 / 1998\end{array}$ & $\begin{array}{l}8 / 26 / 1998- \\
11 / 30 / 2000\end{array}$ \\
\hline & & 2 & $\begin{array}{l}12 / 1 / 2000- \\
5 / 31 / 2003\end{array}$ & $10 / 1 / 2003$ & $10 / 2 / 2003$ & $\begin{array}{l}12 / 1 / 2000- \\
5 / 31 / 2003\end{array}$ & \\
\hline & & 3 & $\begin{array}{l}\text { 6/1/2003- } \\
5 / 31 / 2005\end{array}$ & $8 / 9 / 2007$ & $8 / 9 / 2007$ & $\begin{array}{l}\text { 6/1/2003- } \\
5 / 31 / 2005\end{array}$ & \\
\hline & & 4 & $\begin{array}{l}\text { 6/1/2005- } \\
7 / 31 / 2011 \\
\end{array}$ & 7/9/2007 & $M O U$ & $\begin{array}{l}\text { 6/1/2005- } \\
7 / 8 / 2007 \\
\end{array}$ & $\begin{array}{l}\text { 7/9/2007- } \\
7 / 31 / 2011 \\
\end{array}$ \\
\hline \multirow[t]{4}{*}{ Detectives } & \multirow{4}{*}{$\begin{array}{l}\text { Detectives } \\
\text { Endowment } \\
\text { Association }\end{array}$} & 1 & $\begin{array}{l}10 / 1 / 1992- \\
2 / 21 / 1996\end{array}$ & 3/6/1995 & 3/6/1995 & $\begin{array}{l}\text { 10/1/1992- } \\
\text { 3/5/1995 }\end{array}$ & $\begin{array}{l}3 / 6 / 1995- \\
2 / 21 / 1996\end{array}$ \\
\hline & & 2 & $\begin{array}{l}2 / 22 / 1996- \\
6 / 21 / 2001\end{array}$ & Blank & 9/14/1998 & $\begin{array}{l}\text { 2/22/1996- } \\
9 / 13 / 1998\end{array}$ & $\begin{array}{l}\text { 9/14/1998- } \\
6 / 21 / 2001\end{array}$ \\
\hline & & 3 & $\begin{array}{l}6 / 22 / 2001- \\
2 / 14 / 2004\end{array}$ & $12 / 30 / 2003$ & $12 / 30 / 2003$ & $\begin{array}{l}6 / 22 / 2001- \\
12 / 29 / 2003\end{array}$ & $\begin{array}{l}12 / 30 / 2003- \\
2 / 14 / 2004\end{array}$ \\
\hline & & 4 & $\begin{array}{l}\text { 2/15/2004- } \\
3 / 31 / 2008\end{array}$ & $5 / 7 / 2007$ & $5 / 7 / 2007$ & $\begin{array}{l}\text { 2/15/2004- } \\
5 / 6 / 2007\end{array}$ & $\begin{array}{l}\text { 5/7/2007- } \\
3 / 31 / 2008\end{array}$ \\
\hline
\end{tabular}




\begin{tabular}{|c|c|c|c|c|c|c|c|}
\hline \multicolumn{8}{|c|}{ Appendix Table A-Contract Dates and Status (continued) } \\
\hline Rank & Union & $\begin{array}{l}\text { Contract } \\
\text { Number }\end{array}$ & Contract Dates & $\begin{array}{l}\text { Date Contract Was } \\
\text { Signed by Labor } \\
\text { Relations } \\
\text { Commissioner }\end{array}$ & $\begin{array}{l}\text { Date Contract Was } \\
\text { Registered with } \\
\text { City }\end{array}$ & $\begin{array}{l}\text { Dates Out of } \\
\text { Contract }\end{array}$ & Dates In Contract \\
\hline \multirow[t]{4}{*}{ Lieutenants } & \multirow{4}{*}{$\begin{array}{l}\text { Lieutenants } \\
\text { Benevolent } \\
\text { Association }\end{array}$} & 1 & $\begin{array}{l}8 / 1 / 1995- \\
11 / 30 / 2000\end{array}$ & 11/10/1998 & 11/10/1998 & $\begin{array}{l}8 / 1 / 1995- \\
11 / 9 / 1998\end{array}$ & $\begin{array}{l}\text { 11/10/1998- } \\
11 / 30 / 2000\end{array}$ \\
\hline & & 2 & $\begin{array}{l}\text { 12/1/2000- } \\
6 / 15 / 2003\end{array}$ & $5 / 20 / 2002$ & $5 / 20 / 2002$ & $\begin{array}{l}12 / 1 / 2000- \\
5 / 19 / 2002\end{array}$ & $\begin{array}{l}\text { 5/20/2002- } \\
6 / 15 / 2003\end{array}$ \\
\hline & & 3 & $\begin{array}{l}\text { 6/16/2003- } \\
8 / 31 / 2007\end{array}$ & $11 / 24 / 2006$ & $11 / 24 / 2006$ & $\begin{array}{l}6 / 16 / 2003- \\
11 / 23 / 2006\end{array}$ & $\begin{array}{l}\text { 11/24/2006- } \\
8 / 31 / 2007\end{array}$ \\
\hline & & 4 & $\begin{array}{l}\text { 9/1/2007- } \\
\text { 10/31/2009 }\end{array}$ & $1 / 30 / 2009$ & $1 / 30 / 2009$ & $\begin{array}{l}\text { 9/1/2007- } \\
1 / 29 / 2009 \\
\end{array}$ & $\begin{array}{l}1 / 30 / 2009- \\
10 / 31 / 2009\end{array}$ \\
\hline \multirow[t]{4}{*}{$\begin{array}{l}\text { FDNY- } \\
\text { Firefighters }\end{array}$} & \multirow{4}{*}{$\begin{array}{l}\text { Uniformed } \\
\text { Firefighters } \\
\text { Association of } \\
\text { Greater New } \\
\text { York (UFA) }\end{array}$} & 1 & $\begin{array}{l}1 / 1 / 1995- \\
5 / 31 / 2000\end{array}$ & 10/14/1997 & 10/27/1997 & $\begin{array}{l}1 / 1 / 1995- \\
10 / 13 / 1997\end{array}$ & $\begin{array}{l}10 / 14 / 1997- \\
5 / 31 / 2000\end{array}$ \\
\hline & & 2 & $\begin{array}{l}\text { 6/1/2000- } \\
5 / 31 / 2002\end{array}$ & 9/11/2003 & 9/12/2003 & $\begin{array}{l}6 / 1 / 2000- \\
5 / 31 / 2002\end{array}$ & \\
\hline & & 3 & $\begin{array}{l}\text { 6/1/2002- } \\
7 / 31 / 2006\end{array}$ & $7 / 28 / 2006$ & $7 / 28 / 2006$ & $\begin{array}{l}\text { 6/1/2002- } \\
7 / 27 / 2006\end{array}$ & $\begin{array}{l}\text { 7/28/2006- } \\
7 / 31 / 2006\end{array}$ \\
\hline & & 4 & $\begin{array}{l}\text { 8/1/2006- } \\
7 / 31 / 2008\end{array}$ & $12 / 11 / 2007$ & $12 / 11 / 2007$ & $\begin{array}{l}8 / 1 / 2006- \\
12 / 10 / 2007\end{array}$ & $\begin{array}{l}\text { 12/11/2007- } \\
7 / 31 / 2008\end{array}$ \\
\hline
\end{tabular}

NYC Office of Labor Relations. Registration dates are used for signature dates whenever signature dates are missing. Dates in and out of contract are calculated by the author. 